\title{
Design and Evaluation of a Nondestructive Fissile Assay Device for HTGR Fuel Samples
}
S. R. McNeany
R. W. Knoll
J. D. Jenkins

\section{OAK RIDGE NATIONAL LABORATORY} OPERATED BY UNION CARBIDE CORPORATION · FOR THE DEPARTMENT OF ENERGY 


\section{DISCLAIMER}

This report was prepared as an account of work sponsored by an agency of the United States Government. Neither the United States Government nor any agency Thereof, nor any of their employees, makes any warranty, express or implied, or assumes any legal liability or responsibility for the accuracy, completeness, or usefulness of any information, apparatus, product, or process disclosed, or represents that its use would not infringe privately owned rights. Reference herein to any specific commercial product, process, or service by trade name, trademark, manufacturer, or otherwise does not necessarily constitute or imply its endorsement, recommendation, or favoring by the United States Government or any agency thereof. The views and opinions of authors expressed herein do not necessarily state or reflect those of the United States Government or any agency thereof. 


\section{DISCLAIMER}

Portions of this document may be illegible in electronic image products. Images are produced from the best available original document. 
Printed in the United States of America. Available from National Technical Information Service

U.S. Department of Commerce

5285 Port Royal Road, Springfield, Virginia 22161

Price: Printed Copy $\$ 4.50 ;$ Microfiche $\$ 3.00$

This report was prepared as an account of work sponsored by an agency of the United

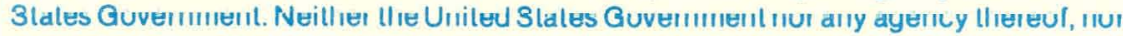
any of their employees, contractors, subcontractors, or their employees, makes any warranty, express or implied, nor assumes any legal liability or responsibility for any third party's use or the results of such use of any information, apparatus, product or process disclosed in this report, nor represents that its use by such third party would not infringe privately owned rights. 
ORNL/TM-6610

Distribution

Category UC-77

Contract No. W-7405-eng-26

Metals and Ceramics Division

Engineering Technology Division

HTGR Fuel Recycle Development Program (189a OHO45)

Fuel Refabrication - Task 500

\section{$\checkmark$ DESIGN AND EVALUATION OF A NONDESTRUCTIVE FISSILE ASSAY DEVICE FOR HTGR FUEL SAMPLES}

S. R. McNeany

R. W. Knoll

J. D. Jenkins

Date Published: February 1979

This report was prepared as an account of work
sponsored by the United States finvermment Noithor the
Unisted States nor the United States Department of
Energy, nor any of their employees, nor any of their
contractors, subcontractors, or their emplnyees, makes
any warranty, express or implied, or assumes any legal
liability ot responsibility for the accuracy, completeness
or usefulness of any information, apparatus, product or
process disclosed, or represents that its use would not
infringe privately owned rights. $\cdots$

OAK RIDGE NATIONAL LABORATORY

Oak Ridge, Tennessee 37830 operated by UNION CARBIDE CORPORATION for the DEPARTMENT OF ENERGY 
THIS PAGE

\section{WAS INTENTIONALLY \\ LEFT BLANK}




\section{CONTENTS}

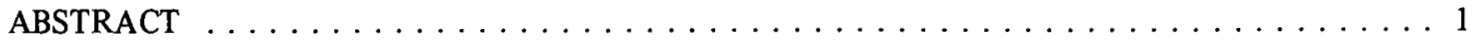

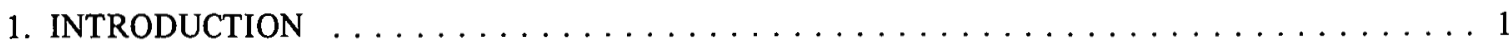

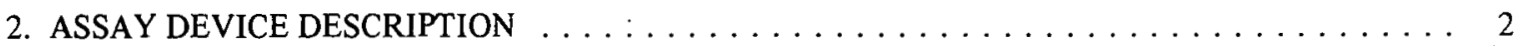

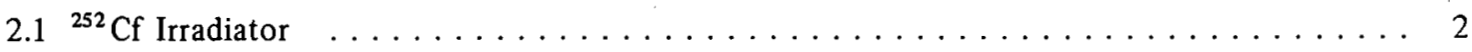

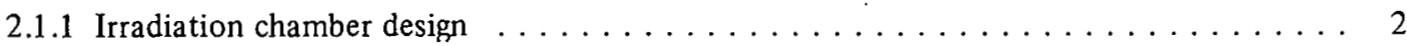

2.1.2 Selection of the moderating material and the source-to-sample distance $\ldots \ldots \ldots 4$

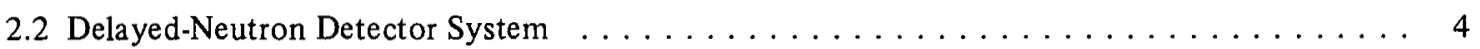

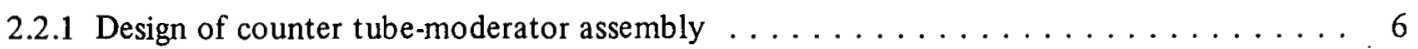

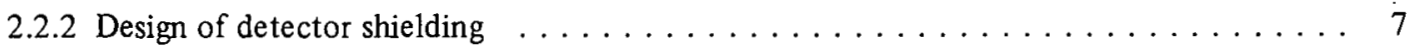

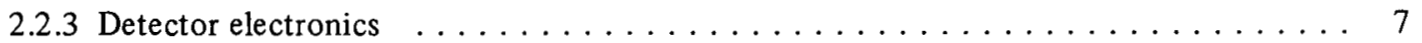

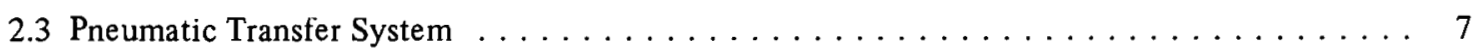

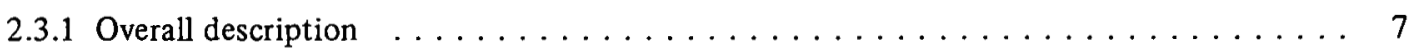

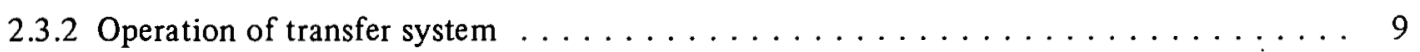

2.4 Programmable Logic Controller and Control Panel . . . . . . . . . . . . . . . . . . . . 9

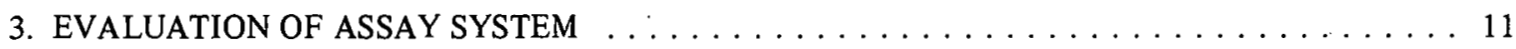

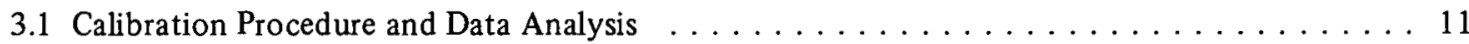

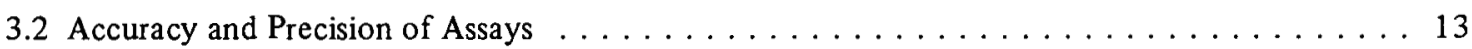

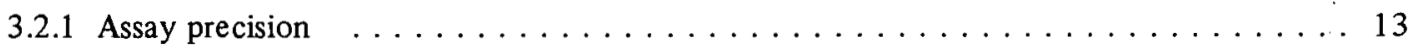

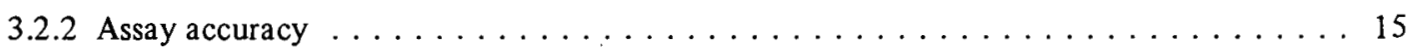

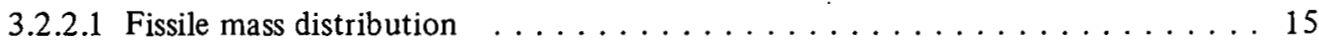

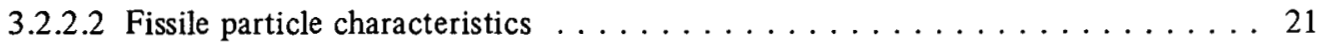

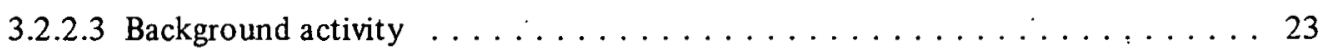

3.2 .2 .4 Source decay $\ldots \ldots \ldots \ldots \ldots \ldots \ldots \ldots \ldots \ldots \ldots$

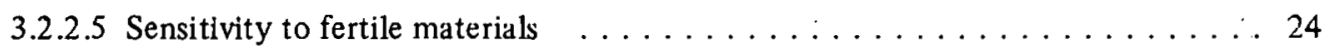

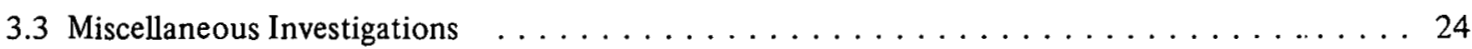

3.3.1 System response to mixtures of ${ }^{233} \mathrm{U}$ and ${ }^{235} \mathrm{U} \ldots \ldots \ldots \ldots \ldots \ldots \ldots$

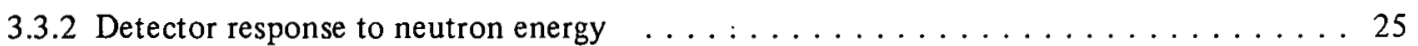

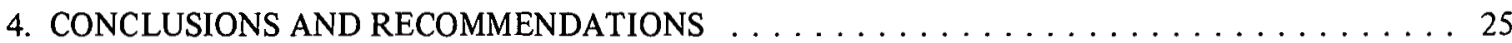

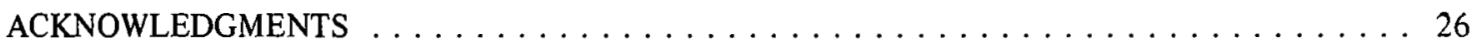

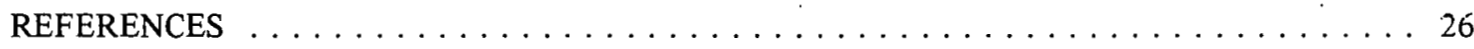

Appendix A - MODIFICATIONS MADE TO PNEUMATIC TRANSFER SYSTEM _ . . . . . . . 27

Appendix B - PROGRAMMABLE LOGIC CONTROLLER PROGRAM _ . . . . . . . . . . . . 29

Appendix $\mathrm{C}-$ OPERATING PROCEDURE $\ldots \ldots \ldots \ldots \ldots \ldots \ldots$ 


\title{
DESIGN AND EVALUATION OF A NONDESTRUCTIVE FISSILE ASSAY DEVICE FOR HTGR FUEL SAMPLES
}

\author{
S. R. McNeany* R.W. Knoll ${ }^{\dagger} \quad$ J. D. Jenkins*
}

\begin{abstract}
Nondestructive assay of fissile material plays an important role in nuclear fuel processing facilities. Information for product quality control, plant criticality safety, and nuclear materials accountability can be obtained from assay devices. All of this is necessary for a safe, efficient, and orderly operation of a production plant. Presented here is a design description and an operational evaluation of a device developed to nondestructively assay small samples of High-Temperature Gas-Cooled Reactor (HTGR) fuel.

The measurement technique employed consists in thermal-neutron irradiation of a sample followed by pneumatic transfer to a high-efficiency neutron detector where delayed neutrons are counted. In general, samples undergo several irradiation and count cycles during a measurement. The total number of delayed-neutron counts accumulated is translated into grams of fissile mass through comparison with the counts accumulated in an identical irradiation and count sequence of calibration standards.

Successful operation of the device through many experiments over a one-year period indicates high operational reliability. Tests of assay precision show this to be better than $0.25 \%$ for measurements of $10 \mathrm{~min}$. Assay biases may be encountered if calibration standards are not representative of unknown samples, but reasonable care in construction and control of standards should lead to no more than $0.2 \%$ bias in the measurements.

Nondestructive fissile assay of HTGR fuel samples by thermal-neutron irradiation and delayedneutron detection has been demonstrated to be a rapid and accurate analysis technique. However, careful attention and control must be given to calibration standards to see that they remain representative of unknown samples.
\end{abstract}

\section{INTRODUCTION}

The conceptual design of the special nuclear material assay and accountability system for an HTGR fuel refabrication plant includes an off-line sample inspection station, which contains a fissile uranium nondestructive assay device. ${ }^{1}$ This device will provide material accountability information for the sample inspection station and will serve as a quality control instrument by performing measurements on samples of HTGR fuel in various stages of production. In addition, the device will serve as a standards calibration facility and will be used to supply calibrated unfired fuel rods to an on-line nondestructive assay machine.

In its accountability and quality control capacities, the device will be required to perform measurements on mixed ${ }^{233} \mathrm{U} /{ }^{235} \mathrm{U}$ fuel in a variety of forms, ranging from hydrogenous dried resin particles to carbonized fuel rods. The assay device must have sufficient throughput capacity to provide one measurement approximately every $13 \mathrm{~min}$. Furthermore, in its function of calibrating secondary standards, the device should be capable of accuracy in the $\pm 0.3 \%$ range for a single measurement with a $95 \%$ level of confidence.

Several different nondestructive assay techniques are being evaluated for use in the sample inspection station, one of which is delayed-neutron counting. The theory behind the technique is quite simple. Nuclear fuel samples undergo fission when exposed to a thermal-neutron flux and generate fission products which

*Engineering Technology Division.

†University of Wisconsin 
decay by neutron emission with half-lives up to $1 \mathrm{~min}$. Examination of samples after irradiation reveals that the average rate of delayed-neutron emission is maximum immediately after the fission process and that the rate decreases exponentially with time. Rapid transfer of an irradiated sample to a neutron detector results in the detection of some fraction of the delayed neutrons. Consequently, samples with higher fissile content will undergo a greater number of fissions, resulting in the detection of a greater number of delayed neutrons. The same principles apply whether the sample is irradiated once and counted once or whether it experiences multiple irradiation and count cycles.

To apply this technique to a quantitative determination of fissile content in unknown samples, it is first necessary to fabricate calibration standards of known fissile content and measure the device response (i.e., number of counts accumulated during an irradiation and detection series) to these known samples. Subsequent measures of response to unknowns can then be translated into fissile content through the use of the calibration data.

The remainder of this report discusses all the major considerations that went into the design and evaluation of this device as a precision measurement instrument. The next section details the design and selection of the four major components of the device. These are the ${ }^{252} \mathrm{Cf}$ neutron irradiator, the delayedneutron detector, the pneumatic transfer system, and the programmable logic controller. Each of these is examined with respect to their nuclear, mechanical, and electrical features. Following this in Sect. 3, attention is turned toward the accuracy and precision of measurements made with the device. Many factors can potentially bias results and reduce precision, and the magnitude of these effects is discussed. Also included in this section is a description of the calibration of the device. Finally, the appendixes present modifications made to the commercially available pneumatic transfer system, details of the programmable logic controller, and an operating procedure.

\section{ASSAY DEVICE DESCRIPTION}

Four main components comprise the delayed-neutron assay device. The first is a thermal-neutron irradiator that uses a removable ${ }^{252} \mathrm{Cf}$ neutron source. Samples are activated in the irradiator, then counted in the second component, à neutron detectur assestully, the heart of which is an array of eight ${ }^{3} \mathrm{He}$ detector tubes. A pneumatic transfer system containing $15 \mathrm{~m}$ ol polyethylene transport tubiny shullles the samples between the irradiator and the detector. The transport system also has a branch for loading and unloading samples. The sequence of events necessary to automatically cycle the sample through the irradiation, transfer, decay, and counting stages is controlled by the fourth componerit, a prugranuinable logic controller (PLC). In this section, each of these components is described in detail, and factors that contributed to their design are discussed.

The assay device is located in the Thorium-Uranium Recycle Facility (TURF) at Oak Ridge National Laboratory, and the components are arranged as shown in Fig. 2.1. In order to protect personnel from the neutron and gamma radiation produced by the unshiclded ${ }^{252} \mathrm{Cf}$ source when experiments are being conducted, the irradiator is situated in a shielded hot cell (cell B). The remainder of the device is located just outside of cell $B$. This arrangement allows ready access to these components, and the cell wall shields the detector assembly from the neutron background produced by the source.

\section{$2.1{ }^{252} \mathrm{Cf}$ Irradiator}

\subsubsection{Irradiation chamber design}

The irradiation chamber is shown in detail in Fig. 2.2. Basically it is a series of concentric cylindrical annuli that surround the sample and moderate the high-energy neutrons emitted by the ${ }^{252} \mathrm{Cf}$ suurce. The 


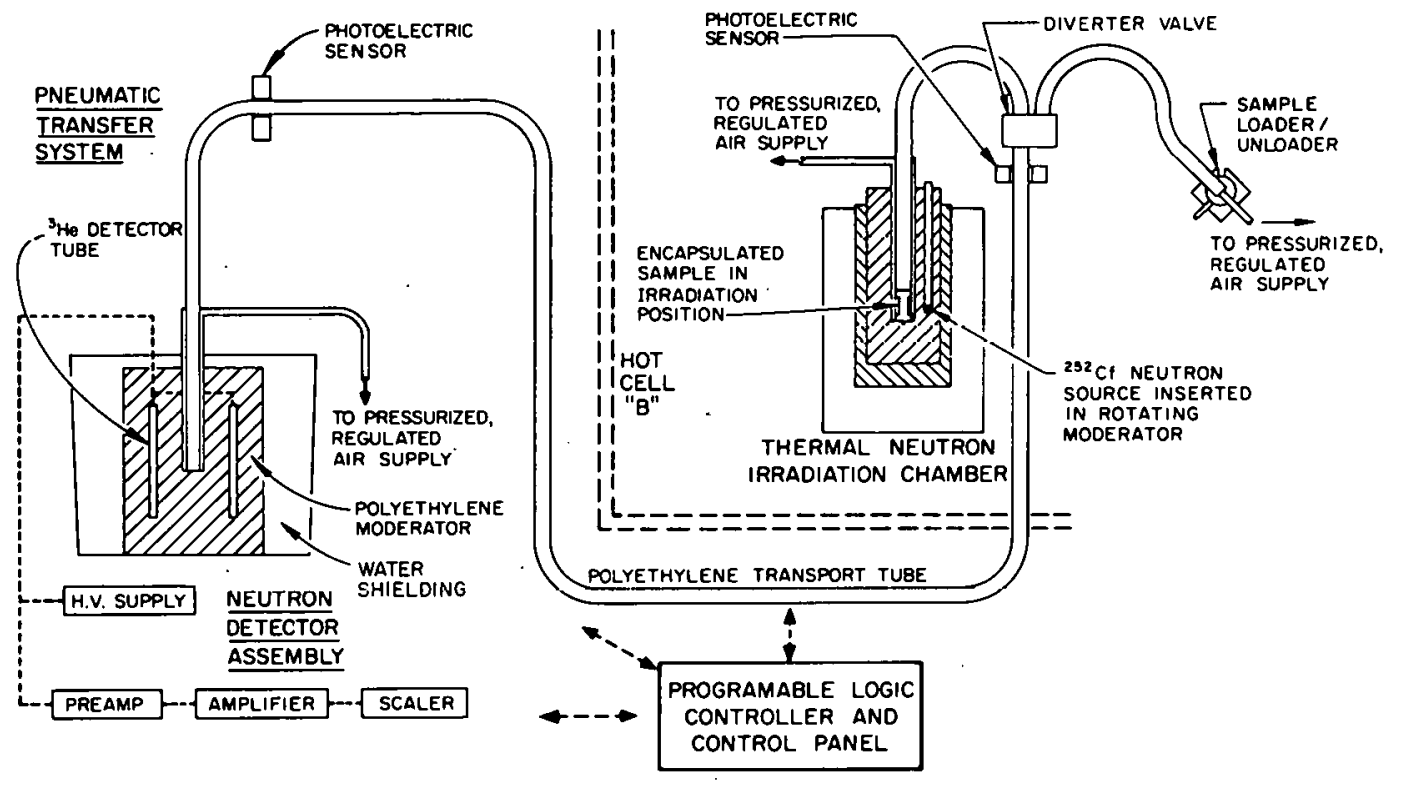

Fig. 2.1. Delayed-neutron nondestructive assay device.

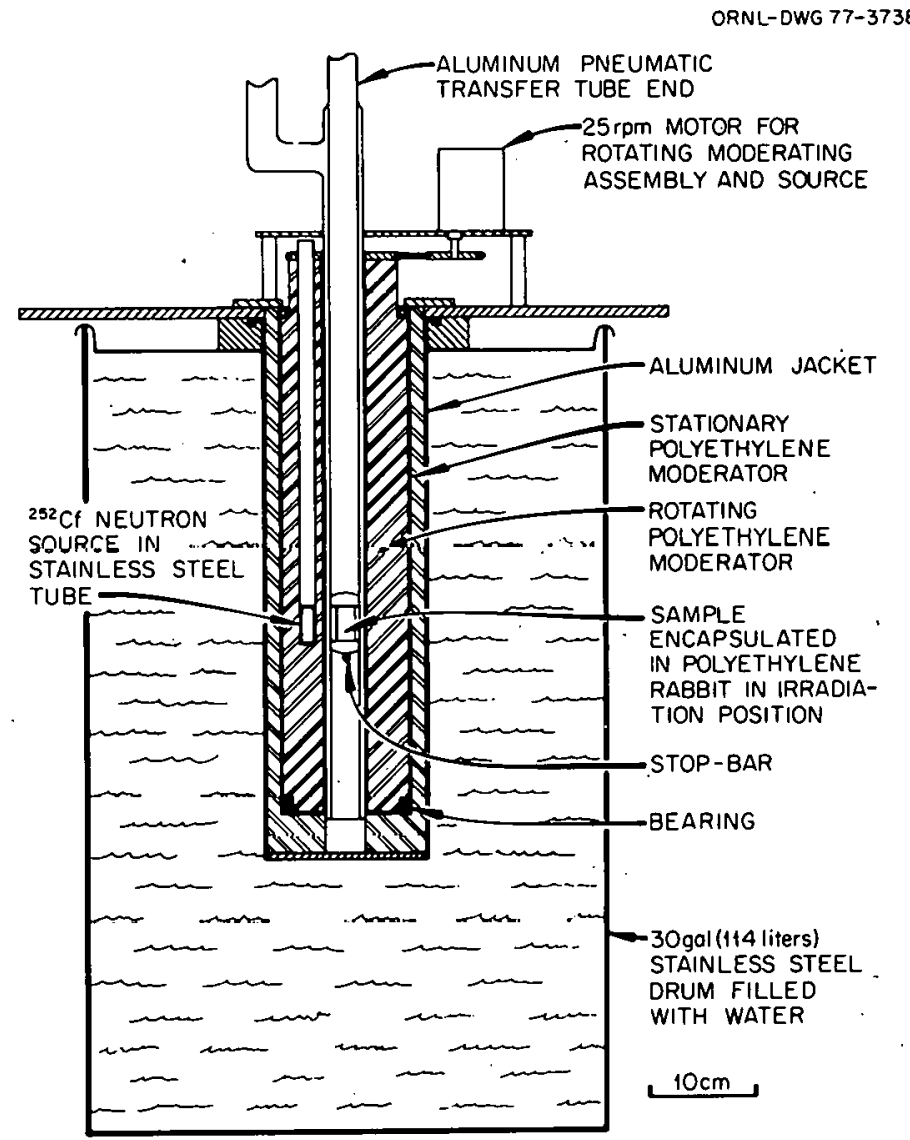

Fig. 2.2. Thermal-neutron irradiator containing ${ }^{252}$ Cf neutron source. 
innermost moderator is an $11.75-\mathrm{cm}-\mathrm{OD}$ by $50.8 \mathrm{-cm}-$ long annulus of machined, high-density polyethylene, whose central hole is $4.13 \mathrm{~cm}$ in diameter. Through this hole the aluminum irradiator end of the pneumatic transfer tube is inserted. The annulus also contains a blind axial hole $(1.63 \mathrm{~cm}$ in diameter by $35.4 \mathrm{~cm}$ deep) that lies $3.51 \mathrm{~cm}$ off center and contains the ${ }^{252} \mathrm{Cf}$ source tube.

To ensure uniform irradiation of the sample (about the vertical axis of the sample), the inner polyethylene annulus and the source it contains are rotated about the pneumatic tube end at about $15 \mathrm{rpm}$. The annulus is mounted in bearings at either end and is attached at the top by a rubber belt drive to a small ac motor. Since the ${ }^{252} \mathrm{Cf}$ is essentially a point source, rotating it about the sample during irradiation gives the time-averaged effect of a ring-shaped source.

The bearings on which the inner moderator is mounted are seated in a high-density, machined polyethylene shell that has a wall thickness of $1.2 \mathrm{~cm}$. At the bottom, the shell closes to a $3.81-\mathrm{cm}$-diam hole in which the bottom of the aluminum pneumatic tube end is fixed. The polyethylene sliell is encased in a 0.318 -cm-thick 6061 aluminum housing suspended from its top in a water-filled 30-gal (114-liter) stainless steel drum. To prevent corrosion of the aluminum housing, its outside surface is coated with a thick layer of epoxy paint. The water in the drum helps moderate the source neutrons and reflects them back into the sample region.

The ${ }^{252} \mathrm{Cf}$ source is contained within a $1.59-\mathrm{cm}$-OD by $37.5-\mathrm{cm}$-long stainless steel tube that can be removed from the irradiator when not in use and stored in a biologically shielded tank within cell $B$. The source itself is sealed in a small metal capsule screwed to the end of a polyethylene rod. The rod is then sealed in the stainless steel source tube. As of July 1, 1978, the source had an activity of $\sim 1.4 \times 10^{9}$ neutrons/sec. The half-life of the ${ }^{252} \mathrm{Cf}$ isotope is 2.63 years, and its specific activity is $\sim 2.3 \times 10^{9}$ neutrons/sec $: \mathrm{mg}$.

\subsubsection{Selection of the moderating material and the source-to-sample distance}

In order to obtain uranium assays of maximum precision from the device, the thermal-neutron flux in the sample region must be as intense as can be obtained from the given source (see Sect. 3.2.1). The intensity of the flux in the sample region depends on the source-to-sample distance and on the type of moderating material used. In the design of the irradiator, both of these factors were determined with the help of the XSDRNPM computer code ${ }^{2}$ Since this code calculates in one dimension only, the irradiatur was modeled as a series of concentric cylindrical annuli of infinite length. The source was treated as a cylindrical sheet surrounding the fuel rod, which was located at the center. A number of cases were then run, varying the type of moderating material and the source-to-sample distance. The fission activity in an HTGR fuel sample containing ${ }^{235} \mathrm{U}$ was calculated and compared from case to case.

Four different moderating materials were considered: $\mathrm{D}_{2} \mathrm{O}$, high-density polyethylene, carbon (graphite), and beryllium. Their performance was in the above order, with $\mathrm{D}_{2} \mathrm{O}$ providing the greatest number of fissions in the ${ }^{235} \mathrm{U}$. However, polyethylene was selected as the moderating material because of its superior engineering properties. The optimum source-to-sample distance, $r$, was determined by varying the radius of the source material from 2.5 to $4.5 \mathrm{~cm}$. The ${ }^{295} \mathrm{U}$ activity was highest with $r=2.5 \mathrm{~cm}$ but decreased by only $2.6 \%$ with $r=3.5 \mathrm{~cm}$. For ease in fabrication of the moderator (drilling of the source tube hole), $r$ was chosen as $3.51 \mathrm{~cm}$. As shown in Sect. 3.2.2.5, the fast-neutron flux obtained with this configuration is low enough that the number of fissions induced in fertile isotopes such as ${ }^{232} \mathrm{Th}$ is small compared with those induced in the tïssile isotopes.

\subsection{Delayed-Neutron Detcctor System}

The overall design of the detector system is indicated in Fig. 2.1. It consists of an ${ }^{3} \mathrm{He}$ proportional counter array, neutron and gamma-ray shielding, and electronic equipment. The structure of the detector 
assembly is shown in the vertical cross-sectional drawing of Fig. 2.3 and in the photograph of Fig. 2.4. In Fig. 2.5, the complete detector assembly encased in a stainless steel can for structural integrity is shown with the aluminum pneumatic tube end in place.

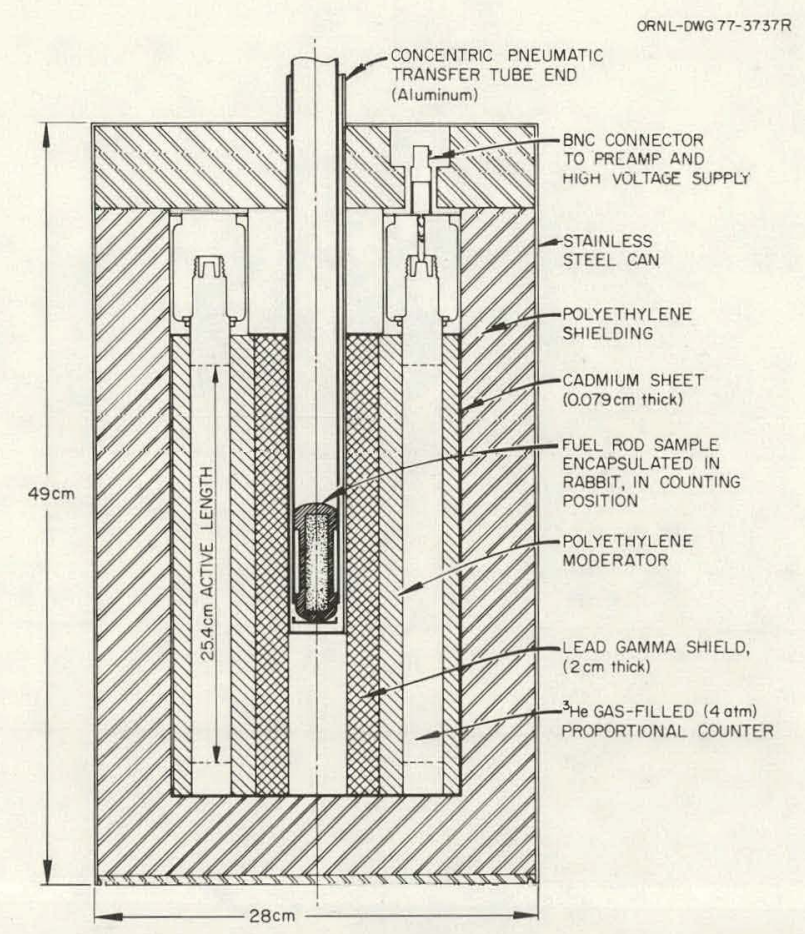

Fig. 2.3. Vertical cross-sectional view of delayed-neutron detector.

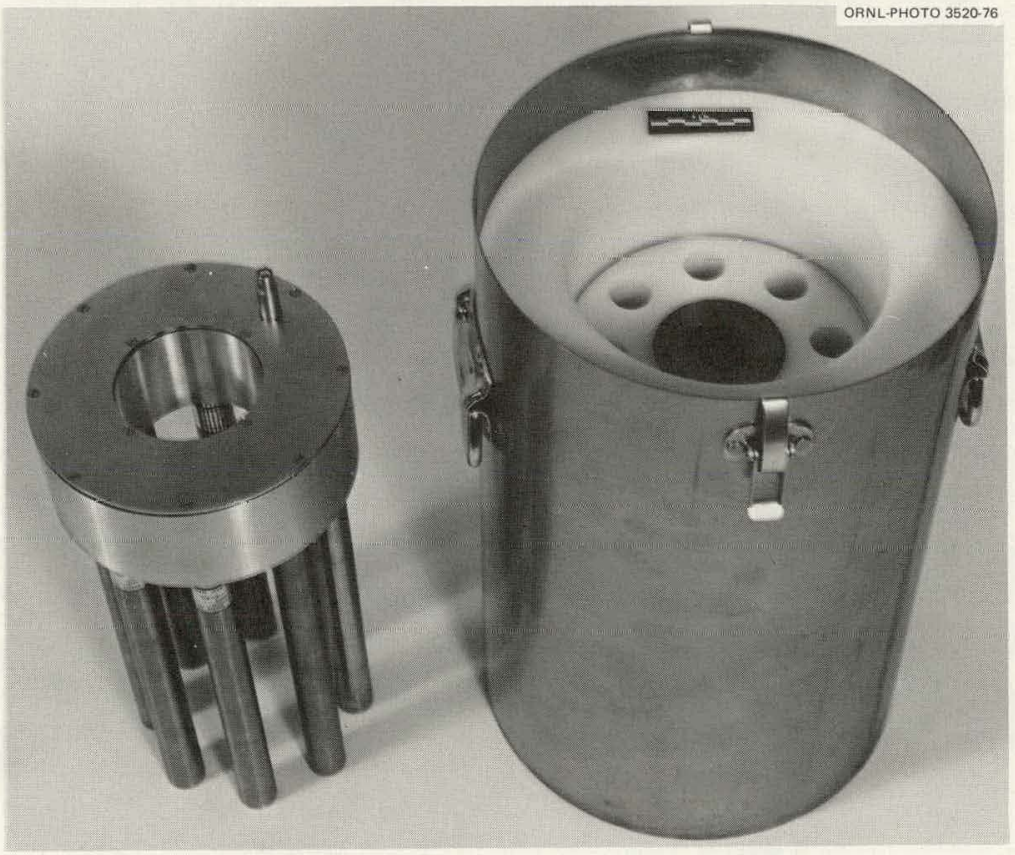

Fig. 2.4. Delayed neutron detector - disassembled 


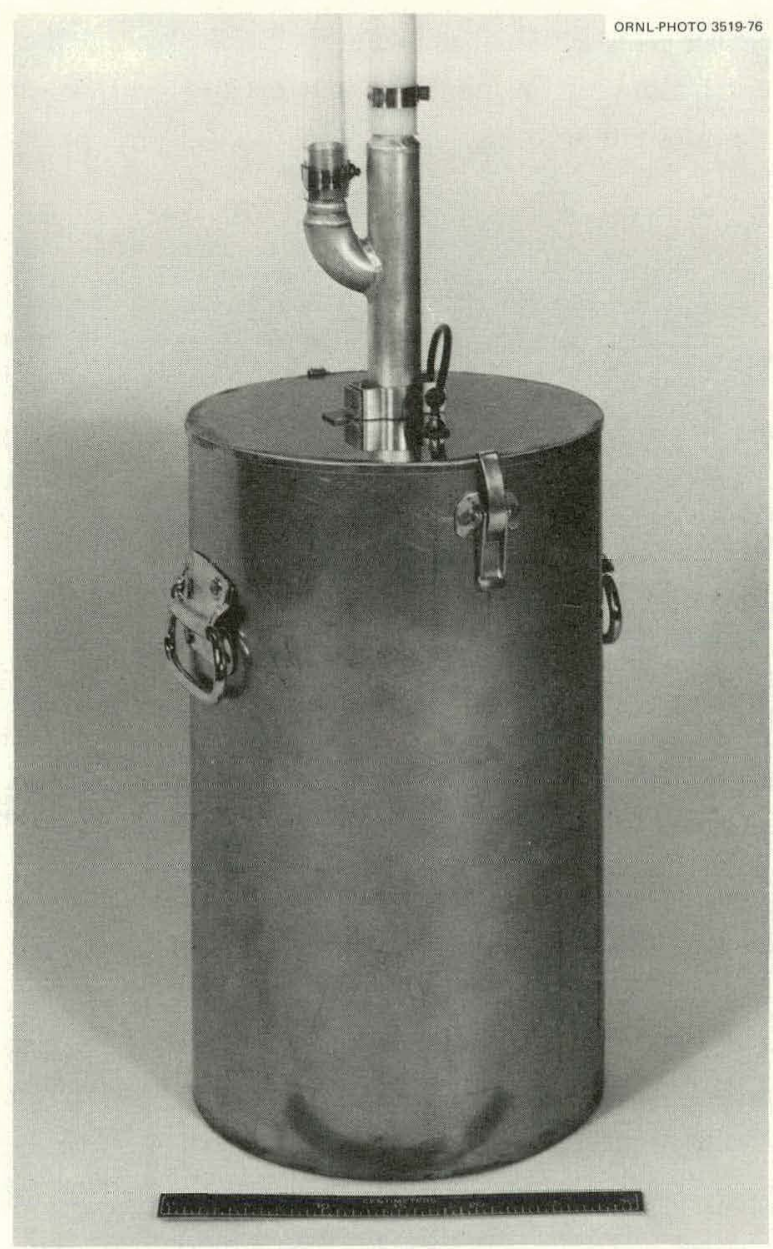

Fig. 2.5. Delayed-neutron detector with pneumatic transfer system installed.

\subsubsection{Design of counter tube-moderator assembly}

The heart of the detector system is a circular array of eight 2.5 -cm-diam ${ }^{3} \mathrm{He}$-gas-filled proportional counters (4 atm gas pressure, $25.4-\mathrm{cm}$ active length) embedded in a cylindrical, high-density polyethylene moderator. The counters, Reuter-Stokes model U564, have closely matched operating characteristics. They are mounted at the top in a torroidal, hermetically sealed metal can, in which they are connected in parallel to a common preamplifier output-high-voltage input.

The design of this assembly, that is, the ${ }^{3} \mathrm{He}$ tube configuration and the dimensions of the polyethylene moderator, was based primarily on a set of guidelines written by LASL personnel ${ }^{3}$ and on calculations that were performed using the Monte Carlo computer code MORSE. ${ }^{4}$ The guidelines indicate the ideal moderator thickness per counter tube for delayed-neutron detection and the relative efficiencies of multiple concentric rings of counter tubes. All of the designs that were initially considered contained two concentric rings of 2.5-cm-diam tubes; the number of tubes per ring and the active length of the tubes were varied, keeping constant the radii of the inner and outer rings ( 6.68 and $10.09 \mathrm{~cm}$ respectively).

The relative detection efficiency of each of these assemblies was calculated using MORSE, which yielded the following results:

1. With both rings containing equal numbers of counter tubes, the detection efficiency of the inner ring was much greater than that of the outer ring. The ratios of inner to outer ring efficiencies for 6,9 , and 12 tubes per ring, respectively, were $2.66,2.59$, and 2.17 . 
2. Considering the inner ring only, doubling the number of tubes from 6 to 12 increased the detection efficiency of the assembly by only $24 \%$.

3. Increasing the active length of the tubes (in both rings) from $25.4 \mathrm{~cm}$ to $30.5 \mathrm{~cm}$ did not significantly increase the efficiency of either ring.

Based on these results and the high cost of ${ }^{3} \mathrm{He}$ tubes, the present design of a single ring of eight 25.4-cm-long tubes was selected.

\subsubsection{Design of detector shielding}

The lead annulus that surrounds the sample shields the ${ }^{3} \mathrm{He}$ tubes from gamma radiation emitted by ${ }^{233} \mathrm{U} /{ }^{235} \mathrm{U}$ fission products and by ${ }^{232} \mathrm{U}$ and its daughter products, which would be present in HTGR recycle fuel samples. ${ }^{1}$ If not screened out, some of this radiation would be detected along with the delayed neutrons. The 2.0 -cm lead thickness was calculated to reduce the dose to the ${ }^{3} \mathrm{He}$ tubes to $\sim 100 \mathrm{mR} / \mathrm{hr}$ from a "worst-case" sample containing $1 \mathrm{~g}{ }^{233} \mathrm{U}$ with $1200 \mathrm{ppm}{ }^{232} \mathrm{U}$, whose daughter products had accumulated for one year. This level of background gamma radiation can be readily discriminated from the delayed-neutron signal.

To shield out neutron radiation originating outside the detector (background radiation), the counter tube-moderator assembly is encased in a 4.8-cm-thick high-density polyethylene shell. Between this shell and the inner moderator is a $0.079-\mathrm{cm}$-thick layer of cadmium. Background neutrons originating outside the detector assembly are thermalized in the shell and absorbed in the cadmium layer before they can reach the counter tubes.

Because large quantities of ${ }^{252} \mathrm{Cf}$ are stored in an adjacent hot cell at TURF, the neutron background in the vicinity of the detector is greater than can be adequately shielded by the polyethylene shell. Thus, additional shielding was added by placing the detector assembly in a water-filled $91 \times 61 \times 61 \mathrm{~cm}$ rectangular tank. This provided a minimum of $12 \mathrm{~cm}$ of water around the detector and reduced the typical background from $\sim 9$ counts/sec to less than 2 counts/sec, an acceptable value.

\subsubsection{Detector electronics}

The electronic components used in the detector system to amplify and count the signals from the ${ }^{3} \mathrm{He}$ tubes consist of a Tennelec TC164 preamplifier, a TC203BLR amplifier, a TC441 single-channel analyzer, and a TC546P scaler. A Tennelec TC940 high-voltage power supply provides the 1000-V dc operating voltage to the counter tubes. The configuration of these components is indicated schematically in Fig. 2.1. A Tracor Northern model TN-1700 multichannel analyzer located near cell B and a PDP 11/40 computer system are also available for use, although they are not integrated into the system.

\subsection{Pneumatic Transfer System}

\subsubsection{Overall description}

With the exception of a pair of photoelectric sensors and a sample load-unload station, the pneumatic transfer system was purchased as a whole from Reactor Experiments, Inc. However, a number of modifications were made to the original system to adapt it to the assay device; primarily, changes were made that allow rapid transfer of the sample without damaging it or the polyethylene rabbit that encapsulated it. As a matter of interest, these modifications are described in Appendix A.

The system as it stands is shown schematically in Fig. 2.6. It consists of an irradiator end and a detector end linked together by $15 \mathrm{~m}$ of $2.86-\mathrm{cm}$-ID polyethylene transport tubing. As indicated in Fig. 2.1, this tube follows a roller-coaster-like path in going from the irradiator to the detector. From the irradiator, the 


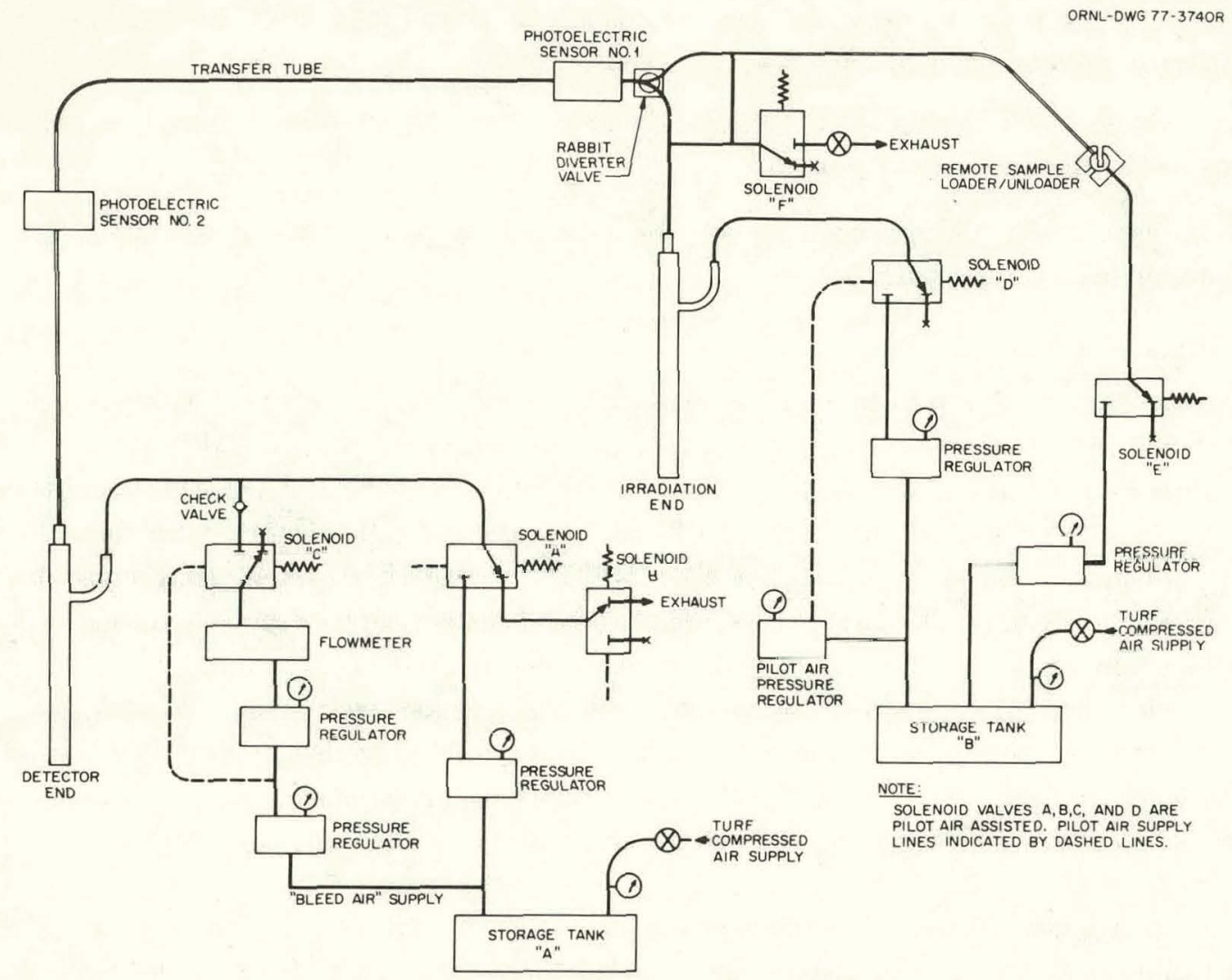

Fig. 2.6. Schematic diagram of pneumatic transfer system.

tube loops down through a hatch in the floor of cell $\mathrm{B}$, passes through a vertical chute, and then travels up to the neutron detector that is approximately at the same elevation as the irradiator. Althnugh this is not an ideal path, it takes advantage of the most accessible entryway to the cell, given the present location of the irradiator and detector.

The sample, which is enclosed in a $2.6-\mathrm{cm}-\mathrm{OD}$ by $6.2-\mathrm{cm}$-long polyethylene rabbit, is propelled through the tube by compressed air regulated to $\sim 10 \mathrm{psi}\left(6.9 \times 10^{4} \mathrm{~N} / \mathrm{m}^{2}\right)$. Compressed air at $85 \mathrm{psi}\left(5.9 \times 10^{5}\right.$ $\mathrm{N} / \mathrm{m}^{2}$ ) is provided to the ballast tanks by TURF air supply lines. The flow of air through the pneumatic system is controlled hy pilnt-air-assisted solenoid valves. Plovivelectric sensors are allached to the pneumatic transfer tube near the detector end and the irradiator end. They detect the rabbit as it passes and provide control signals, as explained below. The detector and irradiator ends of the transfer tube consist of I wo concentric aluminum tubes $(0.16-\mathrm{cm}$ wall thickness), of which the inner tube is a continuatiun of the polyethylene transfer line. The propellent and the exhaust air flow through an annular gap between the inner and outer tubes.

The air supply system at the detector end contains a "bleed-air" provision to supply a constant flow of low-pressure air to the irradiator end during irradiation of the sample. This provision was included in the pneumatic system because, in the original plans for the assay device, the irradiator end was to have been in a livizuntal rather than a vertical position. Thus the low-pressure air flow would push the rabbit against the stop bar in the irradiator end, keeping the sample in a fixed position during irradiation. Since the final design has the irradiator end in a vertical position, use of the bleed-air supply for this purpose is unnecessary. Instead, the bleed-air system is used to shoot an air pulse against the rabbit as it enters the detector end, slowing the rabbit down. 
The remote sample loader-unloader is the final component of the pneumatic transfer system and gives the system complete remote operation capability. The load-unload station operates on a turntable principle. A central, motor-driven cylinder with a receptacle for receiving rabbits can be positioned in three locations. The first location sets the receptacle in a verticle orientation to allow a new sample to be dropped into the loader. From here, the central cylinder can be rotated to align with a branch of the transport tube through which the sample can be transported to the detector. The loader-unloader remains in this position until the sample is ready for unloading, at which time the rabbit is directed back to the unloader. After the rabbit arrives in the central receptacle, the central cylinder is rotated again. This time it moves to a downward passage through which the sample is removed from the system. At this point the central cylinder is returned to the upper vertical location to receive a new sample.

\subsubsection{Operation of transfer system}

Referring to Fig. 2.6, the sequence of events that occur during sample loading or unloading and transfer between the detector and irradiator is as follows. After a sample has been dropped into the loader, its central cylinder is rotated by a small ac motor until the rabbit is aligned with the load-unload branch of the pneumatic transfer tube. The rotation of the motor is interrupted at this point by a limit switch installed in the loader housing. The rabbit diverter valve is set to connect the loading branch with the main section of the pneumatic transfer tube. A $120-\mathrm{V}$ ac signal is applied to solenoid valve $\mathrm{E}$ to allow compressed air to flow through the loader and exhaust out through the detector end and valves $\mathrm{A}$ and $\mathrm{B}$. When the rabbit passes photoelectric sensor 2, solenoid valves $\mathrm{E}$ and $\mathrm{B}$ are closed and solenoid valve $\mathrm{C}$ is opened supplying a pulse of bleed air to slow the rabbit down as it enters the detector.

To begin a series of irradiation and count cycles, the rabbit diverter valve is switched to connect the main section of the transfer tube to the irradiation end. A signal is applied simultaneously to solenoid valves $\mathrm{A}$ and $\mathrm{F}$, which allows regulated compressed air to flow through the detector end, into the transfer tube, and out through the solenoid $\mathrm{F}$ exhaust. When the rabbit passes photoelectric sensor 1, a signal is produced that is used to turn off solenoid A, allowing the rabbit to decelerate as it falls into the irradiator end. Because the air exhausts through the tee above the irradiator end, a dead-air space is created that cushions the rabbit's fall.

The rabbit is propelled back to the detector by a signal that opens solenoid valve D. Compressed air then passes through the irradiator end, into the transfer tube, and into the detector end. It exhausts through solenoid valves A and B. A signal from photoelectric sensor 2 (triggered when the rabbit passes) closes solenoid valve $\mathrm{D}$ and exhaust valve $\mathrm{B}$, allowing the rabbit to fall into the detector end. This signal also opens the bleed-air solenoid valve $C$ that supplies a pulse of air to slow the rabbit down.

The rabbit continues to be shuttled between the detector and the irradiator until a preset number of cycles has been reached. At this point the rabbit is left in the detector and is ready for unloading. The rabbit diverter valve is now set to connect the transfer tube with the unloading branch. As in the case of transfer to the irradiator end, solenoid valves $\mathrm{A}$ and $\mathrm{F}$ are opened. When the rabbit passes photoelectric sensor 1, they are closed and the rabbit falls through a dead-air space into the unloading receptacle. The ac motor attached to the central cylinder of the unloader is activated, rotating the rabbit to the unload position and on around to the verticle load position, where it is stopped by limit switches. A new sample can then be loaded into the system.

\subsection{Programmable Logic Controller and Control Panel}

The programmable logic controller is the focal point of the assay device, in that all of the main components of the device are coupled to and/or controlled by it. The PLC system used here is a Texas 
Instruments model 5TI. This system consists of a sequencer, a programmer, a remote timer and counter preset module, and sets of input and output modules. Components to be controlled by the sequencer (e.g., solenoid valves and panel display lights) are wired to the ac output modules, which are electronic switches that supply $120 \mathrm{~V}$ ac when activated by the sequencer. Input modules are wired to the control panel switches and to the photoelectric sensors. The sequencer, which contains electronic timers, counters, and control relays, senses the state of the input modules and energizes the outputs according to a preprogrammed pattern. Entry of new programs and changes to existing ones are made via the programmer or the remote preset module. Details of the program used to operate the assay device are given in Appendix B.

The 5TI system is mounted with the assay device control panel in an instrument rack, shown in Fig. 2.7. The 5TI-1000 sequencer is at the center of the rack, with the input and output modules mounted below it. The control panel contains a schematic display of the assay device, with pilot lights representing the valves and main system components. During operation of the device, these lights ate energized simultaneously with the components they represent to indicate the progress of the assay cycle. Not shown in the figure is the remote timer and counter preset module (Texas Instruments model 5TI 3200) that allows rapid changes to be made to programmed irradiation times, counting times, and number of irradiation and count cycles.

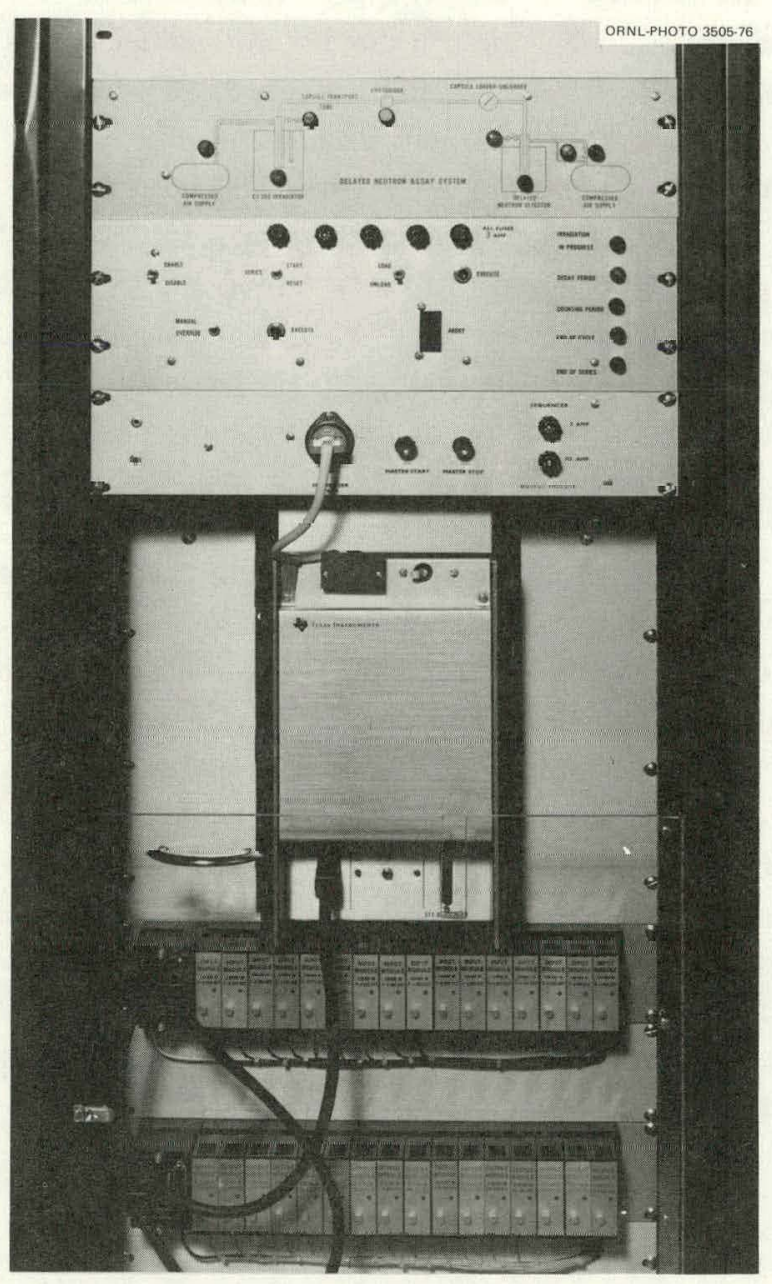

Fig. 2.7. Assay device control pane1. 


\section{EVALUATION OF ASSAY SYSTEM}

The evaluation of the assay system was based primarily on an investigation of the accuracy and precision of its measurements. In performing this evaluation, many experiments were run which were augmented by several analytic studies. A sufficient amount of operating experience was accumulated to state that the device has a very high probability of reliable operation. No major operational problems were encountered during one year of experimental assay measurements. This high reliability can be attributed primarily to the simplicity of the system design.

\subsection{Calibration Procedure and Data Analysis}

Before discussing the evaluation of accuracy and precision it is necessary to make a few introductory remarks about the calibration procedure and method of data analysis. Fundamentally, the device only measures delayed-neutron yields from nuclear fuel samples. To translate these data into fissile content of unknown samples, a functional relationship (i.e., calibration curve) between delayed-neutron counts and fissile mass must be obtained. Different calibration curves will correspond to different fissile isotopes or different mixtures of fissile isotopes. Other factors may also affect calibration curves. For example, HTGR fuel rods composed of particles with high-density kernels require a different calibration curve than rods composed of low-density particles. For another example, different calibration curves would be required for samples of uncoated fuel kernels and samples of fully coated particles. Figure 3.1 shows a sample calibration curve obtained from HTGR fuel rods composed of low-density fuel particles.

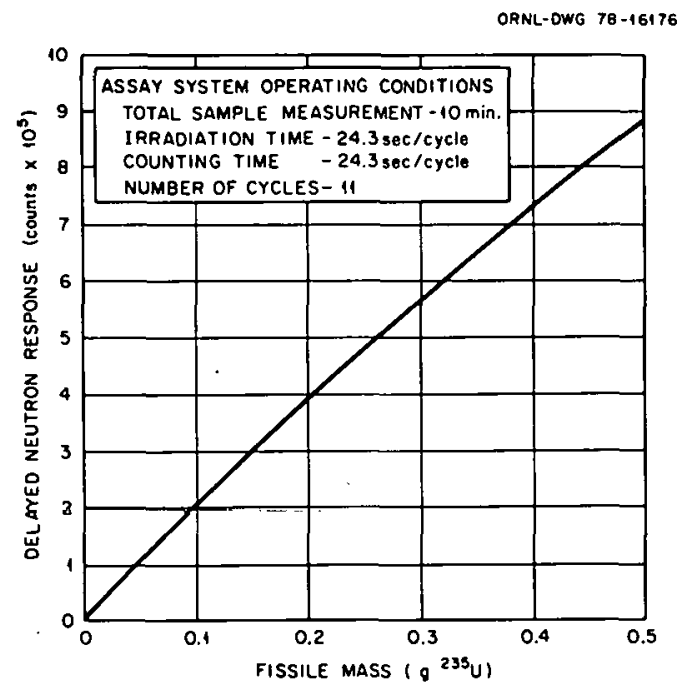

Fig. 3.1. Calibration curve obtained from HTGR fuel rods composed of low-density fuel particles.

Typical calibration curves are approximated quite well by Eq. (3.1):

$$
C=A\left(1-e^{-B X}\right)
$$

where

$C$ is the number of counts accumulated,

$A$ arid $B$ are constants,

$X$ is the fissile mass. 
The constants $A$ and $B$ are determined by a least-squares fit of calibration data collected on standards of known fissile content. Fabrication of standards and measurement of the response must be performed very carefully to prevent biases in future assays.

From the above equation it is apparent that the counts accumulated during an assay approach an upper limit as the fissile mass increases. Consequently, the assay system becomes less sensitive to changes in mass as fissile mass increases. However, the maximum fissile mass expected for assay by this device is $0.5 \mathrm{~g}$, and as seen from Fig. 3.1 the system sensitivity over this range does not decrease significantly.

Since $X$ in Eq. (3.1) is the desired result of an assay, and $C$ is the directly measured quantity, a more useful form of the equation for measurement purposes is its inverted form:

$$
X=\frac{1}{B} \ln \left(\frac{A}{A-C}\right) .
$$

Measured counts from unknown samples can be inserted into Eq. (3.2) to obtain the desired fissile content.

One additional point is noted before proceeding with the details on evaluation of precision and accuracy. Using Eq. (3.2), another equation can be derived that describes the sensitivity of changes or variations in the observed count on the resulting fissile content. For small changes in the count, the corresponding change in the fissile content can be approximated by Eq. (3.3):

$$
\Delta(X) \approx \frac{d X}{d C} \Delta(C)
$$

where the delta notation indicates change in the bracketed variable. From Eq. (3.2),

$$
\begin{aligned}
& \frac{d X}{d C}=\frac{1}{B(A-C)}, \\
& \Delta(X) \approx \frac{1}{B(A-C)} \Delta(C) .
\end{aligned}
$$

On a fractional basis,

$$
\frac{\Lambda(X)}{X} \approx \frac{\Delta(C)}{(A-C) \ln \left(\frac{A}{A-C}\right)}
$$

Since $A$ is usually four to ten times larger than $\mathrm{C},{ }^{*}$ a final approximation can be applied to Eq. (3.6) to arrive at Eq. (3.7):

$$
\Delta X / X \approx \Delta C / C
$$

Hence, a percentage change or uncertainty in a fissile mass determination is approximately equal to the percentage change or uncertainty in the measured delayed-neutron counts. This relationship is used often in the following sections for precision and accuracy evaluations.

*Ten irradiation and count cycles were made for each measurement. 


\subsection{Accuracy and Precision of Assays}

In this evaluation a distinction is made between accuracy and precision. The following are definitions of the terms as they are used in this report:

Precision - the degree to which the results of an assay are repeatable.

Accuracy - the degree to which the results of an assay agree with the true amount of fissile material in samples.

Accordingly, a measurement may be highly precise and yet it may be totally inaccurate. The reverse statement is not true. Accuracy is limited by the precision of the measurement.

\subsubsection{Assay precision}

The precision of assays made with the device is composed of two components. First, uncertainties are introduccd due to the limited control capability of the programmable logic controller and the limited response ability of the pneumatic transfer system. Due to these limitations, run-to-run variations may be observed in specified irradiation times, counting times, and transport times. These will result in different responses from a sample undergoing repeated measurements with identical test conditions. Of these variations, the factor of greatest concern is the degree of variation in the time lapse between the end of irradiation and the start of the counting period. To minimize the potential uncertainties in this phase of the measurement cycle, a time interval of $4.5 \mathrm{sec}$ is allowed for transfer. In this way, assurance is given that the sample has had sufficient time to travel from the irradiator to the detector $(2.0 \mathrm{sec}$ is the maximum observed time). Also, this interval allows the very-short-lived delayed-neutron precursors of high activity to decay so that any variations in the transfer time will have minimal impact on the total count.

The inherent randomness of the nuclear decay process is the second component of assay precision which leads to variation in the measured counts. That is, even if the sample transport and control operations had absolute precision, repeated measurements of a given sample would still yield different results. This effect is unavoidable but can be minimized through selection of optimum operating procedures. A study ${ }^{5}$ investigating the statistical nature of delayed-neutron counting addresses this issue. The principal results of that study are repeated here. The most fundamental result is that counts accumulated during multiple irradiation and count cycles are not governed by Poisson statistics as typically found in nuclear counting situations. A correlation between counts accumulated in individual cycles leads to statistical relationships that contain covariance effects. Consequently, statistically optimized irradiation and counting times do not necessarily result in a maximized total count. Covariance effects are most prominent in systems with very short time intervals between irradiation and counting intervals, but they have a slight impact on the selection of operating parameters for the HTGR system. Table 3.1 lists optimum operating conditions for various-length measurements on ${ }^{233} \mathrm{U}$ and ${ }^{235} \mathrm{U}$, the two fissile nuclides in HTGR fuel. It is interesting to note that when covariance effects are accounted for, the optimum number of irradiation and count cycles for a fixed measurement time is generally less than those based on maximization of the count. Thus, although improvements in statistical precision are small, less wear and tear on the system results when the parameters selected by this detailed analysis are used. As expected, the study also indicates that statistical precision is improved as thermal-neutron flux increases and as detector efficiency increases.

To experimentally determine the overall assay precision of the device, a series of repeated measurements of fuel samples was conducted. A wide variety of operating parameters was investigated. In Table 3.2, data collected for five separate measurements made on a sample fuel rod containing $0.15 \mathrm{~g}$ of highly 
Table 3.1. Statistically optimized operating conditions for the HTGR small-sample assay device

\begin{tabular}{|c|c|c|c|c|c|c|}
\hline \multirow{3}{*}{$\begin{array}{c}\text { Total } \\
\text { measurement } \\
\text { time } \\
\text { (min) }\end{array}$} & \multicolumn{6}{|c|}{ Operating parameters } \\
\hline & \multicolumn{3}{|c|}{${ }^{235} \mathrm{U}$ samples } & \multicolumn{3}{|c|}{${ }^{233} \mathrm{U}$ samples } \\
\hline & $\begin{array}{l}\text { No. of } \\
\text { cycles }\end{array}$ & $R=t_{I} / t_{C}$ & $\begin{array}{l}\text { Coefficient of } \\
\text { variation } \\
\text { (normalized) }\end{array}$ & $\begin{array}{l}\text { No. of } \\
\text { cycles }\end{array}$ & $R=t_{I} / t_{C}$ & $\begin{array}{l}\text { Coefficient of } \\
\text { variation }{ }^{a} \\
\text { (normalized) }\end{array}$ \\
\hline 1 & 1 & 1.000 & 18.67 & 1 & 1.000 & 27.07 \\
\hline 10 & 15 & 1.040 & 5.525 & 12 & 1.041 & 7.997 \\
\hline 30 & 45 & 1.045 & 3.171 & 38 & 1.048 & 4.583 \\
\hline 60 & 90 & 1.045 & 2.239 & 76 & 1.048 & 3.234 \\
\hline 300 & 451 & 1.045 & .1 .000 & 383 & 1.048 & 1.444 \\
\hline
\end{tabular}

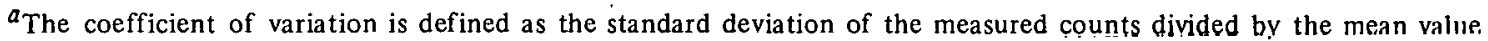
of the counts and multiplied by 100 . In this case the coefficient is normalized to 1.000 for a $300-s e c$ measurement on ${ }^{235} \mathrm{U}$.

Table 3.2. Sampie dátá ó counts collected from five repeated measurements of an HTGR fuel rod

\begin{tabular}{|c|c|c|c|c|c|c|c|}
\hline \multirow{2}{*}{ Cycle/Trial } & \multicolumn{5}{|c|}{ Counts accumulated per cycle ${ }^{a}$} & \multirow{2}{*}{ Mean } & \multirow{2}{*}{$\begin{array}{c}\text { Stand. } \\
\text { Dev. }\end{array}$} \\
\hline & 1 & 2 & 3 & 4 & 5 & & \\
\hline 1 & 28,632 & 28,914 & 28,519 & 28,564 & 29.027 & 28.7 .31 & 2.26 \\
\hline 2 & 31,928 & 31,939 & 32,013 & 31,747 & 32,063 & 31,938 & 120 \\
\hline 3 & 33,278 & 32,804 & 32,924 & 32,822 & 32,623 & 32,890 & 242 \\
\hline 4 & 33,183 & 32,898 & 33,014 & 33,153 & 32,831 & 33,016 & 154 \\
\hline 5 & 33,298 & 33,211 & 32,996 & 33,210 & 33,155 & 33,174 & 112 \\
\hline 6 & 33,222 & 33,498 & 33,045 & 33,077 & 32,945 & 33,157 & 215 \\
\hline 7 & 33,200 & 33,162 & 33,320 & 33,183 & 33,201 & 33,213 & 62 \\
\hline 8 & 33,456 & 33,602 & 33,121 & 33,295 & 33,139 & 33,323 & 207 \\
\hline 9 & 32,839 & 33,512 & 33,396 & 34,093 & 33,251 & 33,418 & 455 \\
\hline 10 & 33,285 & 33,782 & 33,090 & 32,524 & 33,386 & 33,213 & 461 \\
\hline \multirow[t]{3}{*}{ Total } & 326,321 & 327,322 & 325,438 & 325,668 & 325.621 & $326,(1) 74$ & 77.3 \\
\hline & & & & & \multicolumn{3}{|c|}{ Coefficient of variation $=\frac{773}{326,074} \times 100 \%$} \\
\hline & & & & & & $=0.2$ & \\
\hline
\end{tabular}

Operatıng parameters:

Total measurcment time, $10 \mathrm{~min}$

Irradiation time, $25.7 \mathrm{sec} / \mathrm{cycle}$

Counting timc, $25.7 \mathrm{scc} / \mathrm{cyclc}$

Number of cycles, 10

Known fissile content of sample: $0.1496 \mathrm{~g}{ }^{235} \mathrm{U}$

${ }^{a}$ Counts are corrected for a small background activity.

enriched ( $(93 \%){ }^{235} \mathrm{U}$ art: given.* The column headings of the table correspond to the five measurements, their mean, and their standard deviation. Listed vertically are the irradiation and count cycle numbers with the corresponding number of counts accumulated in each cycle. At the bottom is the total number of counts accumulated for all cycles in each measurement. Recalling Sect. 3.1, note that the coefficient of variation in the number of counts closely approximates the coefficient of variation in the assayed fissile

\footnotetext{
*For the calibration curve of Fig. $3.1, A=2.8 \times 10^{6}$, while counts at calibration points ranged from $0.3 \times 10^{6}$ to 0.8
} $\times 10^{6}$. 
mass. Thus the coefficient of variation of the assay results corresponding to these sample measurements is $0.24 \%$. Other $10-\mathrm{min}$ assays had variations averaging around $0.15 \%$. Using the theory presented in ref. 5 , the calculated statistical variation of these measurements should be approximately $0.18 \%$. It can be concluded from these results that the precision of assays made with this device is primarily due to statistical effects and that variations in the operation and control components are insignificant in comparison. Also, the precision of $10-\mathrm{min}$ assays is sufficient to meet the design requirement of $0.30 \%$.

\subsubsection{Assay accuracy}

Assays are made by measuring the delayed-neutron yields of unknown samples and then comparing the accumulated count with those obtained from an identical measurement of calibration standards to arrive at a fissile content for the unknown. Hence, any differences between the calibration standards and the unknowns with respect to fissile mass distributions or particle kernel densities may potentially bias the results. For example, if individual fuel rods are being assayed under conditions where calibration standards have a uniform fissile mass distribution and unknowns have a $20 \%$ higher fissile mass concentration in the center than on the ends, then a slight bias may be introduced into the results. Other factors such as neutron source decay; changes in neutron background activity, and system sensitivity to the fertile content of samples all may affect the results of assays. Each of these is discussed in detail below.

3.2.2.1 Fissile mass distribution. Differences between the fissile mass properties and distributions in calibration standards and unknown samples can lead to biased assay results. Usually no correction can be made for this effect. However, the effect can be minimized by carefully constructing calibration standards to closely resemble the fissile distribution in the samples to be assayed. To simplify this analysis, all measurements to be made by the assay device can be viewed as measurements on samples of fuel particles. The samples are either in the form of loose particles restrained in a rabbit or particles dispersed throughout the volume of a molded fuel rod. In either case, assay results are influenced by the fissile mass distribution in the sample as a whole, as well as the fissile properties of the individual fuel particles. For additional simplicity, assume that all samples are in the form of molded fuel rods. The same results apply to collections of loose particles.

First, consider the effects on accuracy of the fissile distribution in the sample as a whole. Uniform fissile concentration throughout the rod is the goal of the rod production process. In practice, production rods will approach this standard, but they will always have some nonuniform component. By assuming calibration rods to be perfectly uniform and by examining several assumed fissile distributions in unknowns, an estimate can be made of the biases that will result. Below is an analysis of distribution variations in each of the three spatial directions.

Axial effects. The system assay response can be written as the product of the irradiator flux, the detector sensitivity function, and the fissile mass distribution integrated over the volume of the fuel rod. For examination of axial mass distribution effects, all radial and azimuthal components of the above functions are taken to be uniform. Neutron self-shielding effects are presently ignored but are considered later with respect to radial effects.

The axial flux distribution in the irradiator has been determined experimentally through the use of neutron activation analysis. The absorber selected for this experiment was ${ }^{197} \mathrm{Au}$, which forms the unstable isotope ${ }^{198} \mathrm{Au}$ upon the capture of a thermal neutron, as shown in Eq. (3.8):

$$
{ }^{197} \mathrm{Au} \stackrel{(n, \gamma)}{\longrightarrow}{ }^{198} \mathrm{Au} \frac{(\beta, \gamma)}{2.696 d}{ }^{198} \mathrm{Hg}
$$


For measurements of this type, it can be shown that the neutron flux to which the absorber was exposed is given by

$$
\phi=\frac{A_{8}}{N_{7} \sigma_{a_{7}}\left(1-e^{-\lambda_{8} t}\right)},
$$

where

$$
\phi=\text { thermal-neutron flux (neutrons } / \mathrm{cm}^{2} \cdot \mathrm{sec} \text { ), }
$$

$A_{8}={ }^{198} \mathrm{Au}$ activity at the end of irradiation (disintegrations/sec),

$N_{7}=$ number of ${ }^{197} \mathrm{Au}$ target nuclei,

$\sigma_{a_{7}}=$ microscopic thermal-neutron absorption cross section for ${ }^{197} \mathrm{Au}\left(\mathrm{cm}^{2}\right)$,

$\lambda_{8}=$ radioactive decay constant for ${ }^{198} \mathrm{Au}\left(\mathrm{sec}^{-1}\right)$,

$t=$ irradiation time (sec).

A gold wire 10 mils $(0.0254 \mathrm{~cm})$ in diameter was selected for activation in this experiment. The wire was first cleaned to remove all surface contamination and then installed in a specially prepared fuel rod to hold it during irradiation. The wire was placed through the axial center of the rod and along the rod's outer surface. Figure 3.2 shows a diagram of the wire-containing rod and a polyethylene transfer rabbit used to convey the sample to the irradiator. The fuel rod is the same size as those used in the Fort St. Vrain reactor $\left(1.24 \mathrm{~cm}\right.$ in diameter by $4.93 \mathrm{~cm}$ long; , and it was fabricated of $\mathrm{ThO}_{2}$-bearing particles only. No fissile material was contained in the rod, so that the flux determination yields a result characterized by the absence of neutron self-shielding.

The loaded rabbit was then positioned in the irradiation chamber and irrauiated for $66 \mathrm{hr}$. After the activation period, the rabbit was removed from the irradiator, and both the inner and outer gold wires were cut into eight segments of approximately equal length. Each segment was then weighed and counted to determine the ${ }^{198} \mathrm{Au}$ activity. With the weight of the wires and their activities known, Eq. (3.9) was then solved for the absolute thermal-neutron flux.

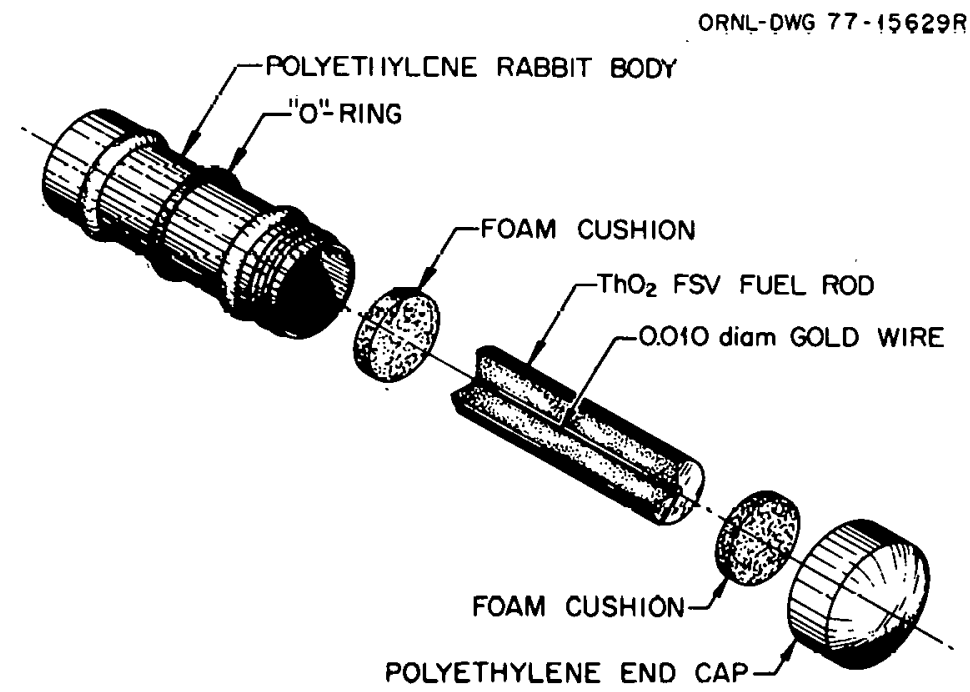

Fig. 3.2. Gold wire encapsulation for thermal-neutron flux measurement. 
The results of the activation experiment are presented graphically in Fig. 3.3, where the absolute thermal-neutron flux is shown to be a function of the height above the bottom of the irradiation chamber. Table 3.3 gives the average values of the flux and the maximum variation from the average for the wires located at the surface and the center of the fuel specimen. As seen from both Fig. 3.3 and Table 3.3, the flux in the radial direction is essentially constant throughout the fuel sample. The dip in the flux observed near the center of the outside wire is due to the presence of the neoprene O-ring on the rabbit. This was included to improve the transport characteristics of the rabbit; however, its flux-depressing properties were considered to be detrimental, and the ring is no longer used.

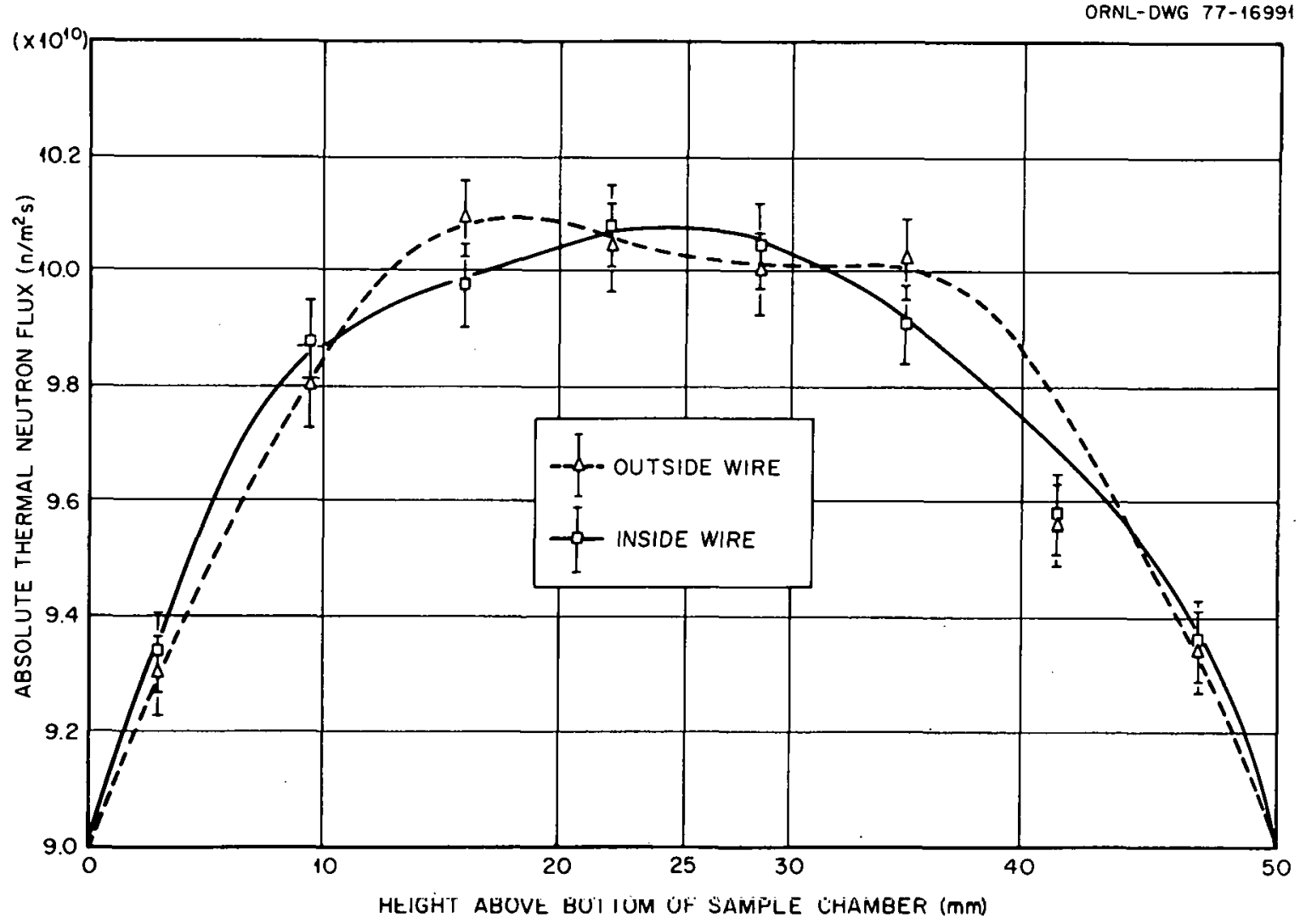

Fig. 3.3. Axial thermal-neutron flux in the neutron irradiator.

Table 3.3. Absolute thermal-neutron flux in the delayed neutron nondestructive assay device ${ }^{a}$

\begin{tabular}{lcc}
\hline $\begin{array}{c}\text { Radial wire } \\
\text { location }\end{array}$ & $\begin{array}{c}\text { Absolute flux } \\
\left.\text { (neutrons } / \mathrm{cm}^{2} \cdot \mathrm{sec}\right)\end{array}$ & $\begin{array}{c}\text { Maximum axial variation } \\
\text { from average } \\
(\%)\end{array}$ \\
\hline Outside & $9.772 \times 10^{6}$ & 4.7 \\
Center & $9.769 \times 10^{6}$ & 4.4 \\
\hline
\end{tabular}

${ }^{a}$ At the time of this measurement, there was $762 \mu \mathrm{g}$ of ${ }^{252} \mathrm{Cf}$ in the source having an activity of $\sim 1.75 \times 10^{9}$ neutrons/sec. 
For later inclusion as a component of the flux-detection mass distribution integral, the flux was approximated by a normalized sine function of Eq. (3.10):

$$
\phi(x)=1.0301 \sin (0.8416 x+1.15)
$$

Figure 3.4 shows how the function fits the measured data points.

ORNL-OWG 77-16990

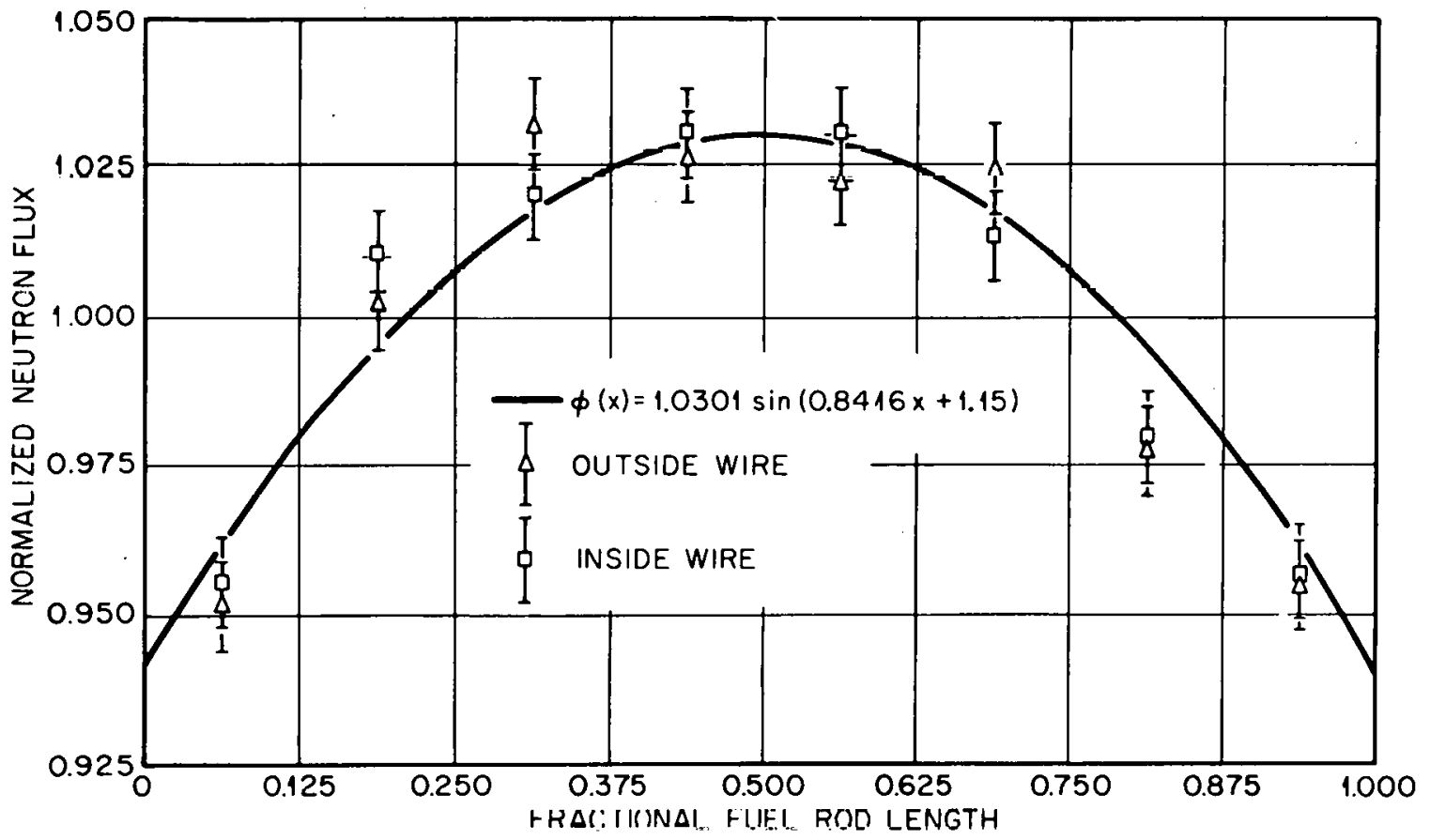

Fig. 3.4. Measured neutron flux and approximathig sine funcilon.

The relative sensitivity of the detector with respect to the axial position of the sample was also measured. A small vial containing $\sim 1 \mu \mathrm{g}{ }^{252} \mathrm{Cf}$ in solution was suspended at a number of vertical positions (on the central axis) in the detector and counted to determine the relative detection efficiency with respect to axial sample position. A 100-sec count was taken at each of 11 positions, and the relative counts/sec were plotted (Fig. 3.5). As evident from the plot, the detector response is quite flat over the normal sample counting position (within $\pm 2.5 \mathrm{~cm}$ of the horizontal midplane). Similarly to the flux measurement above, a normalized sine function was fit to the measured data. The resulting detector efficiency function is given by Eq. (3.11):

$$
\epsilon(X)=1.0065 \sin (0.3947 X+1.3734),
$$

where $X$ is the fractional height above the bottom of the detector sample chamber (i.e., 0 at the bottom, 1 at the top) and $\epsilon(X)$ is the relative detector efficiency at height $X$.

Six hypothetical fissile distributions, shown in Fig. 3.6, were selected to determine the magnitude of the variations in the device response. These distributions range from a uniform case corresponding to 


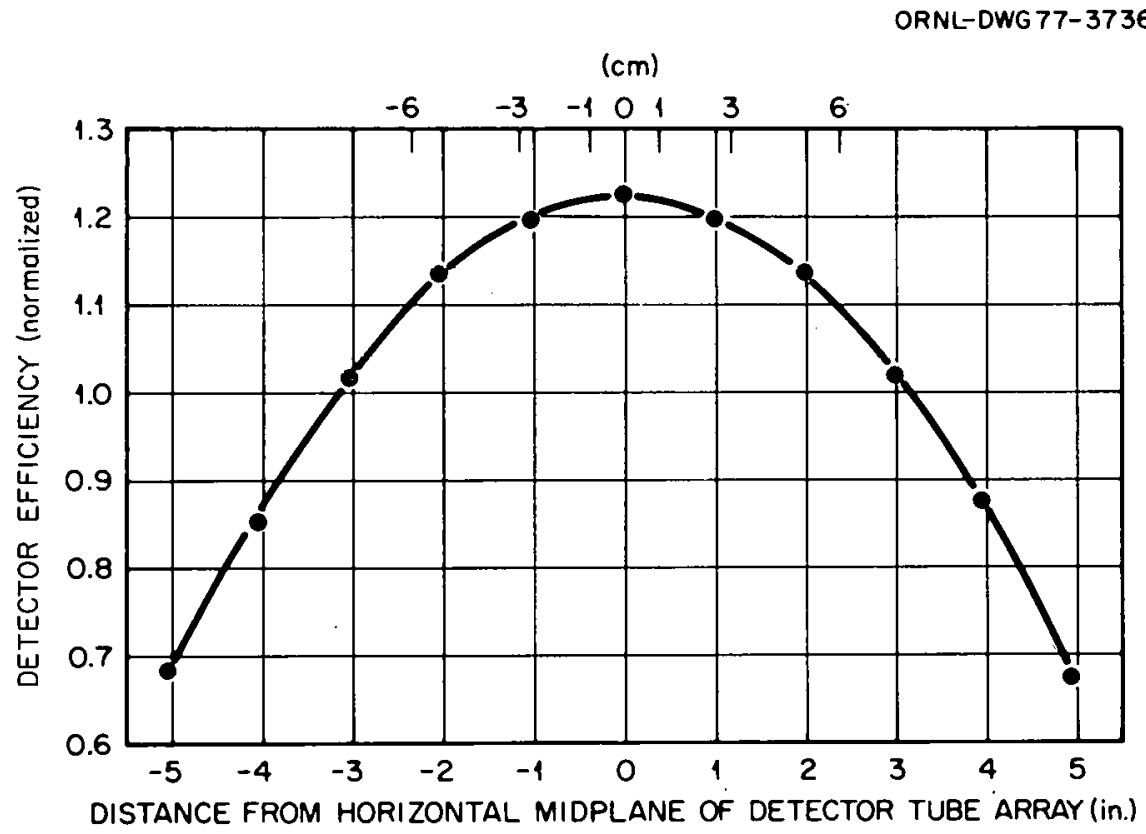

Fig. 3.5. Detector efficiency vs axial position of sample.

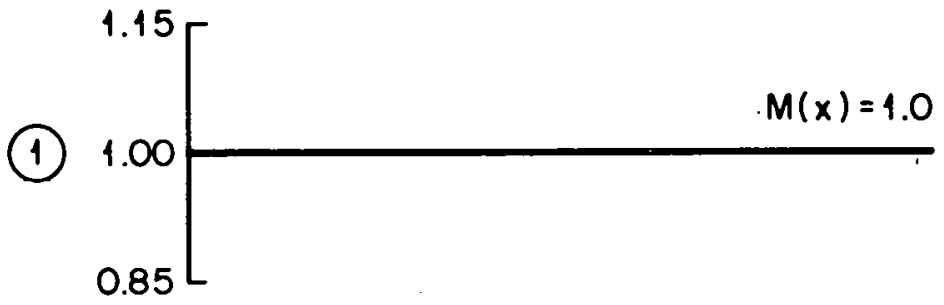

(2)

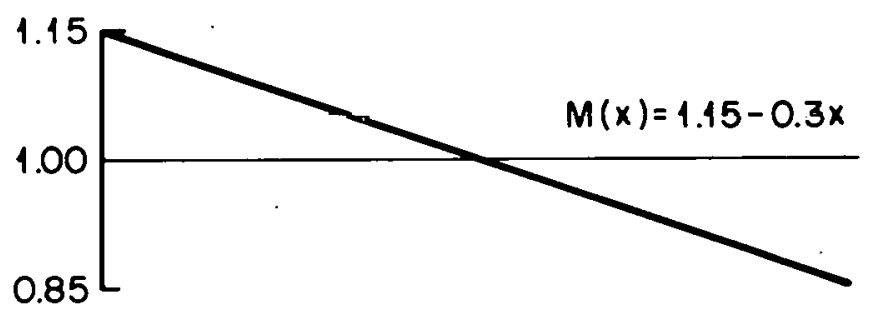

(3)

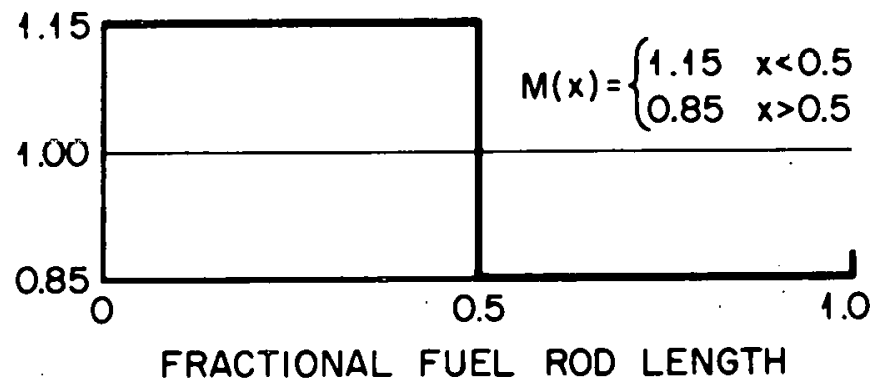

Flg. 3.6. Hypothetical fissile mass distributions used to study the effects of axial fucl hetcrogencitics. 

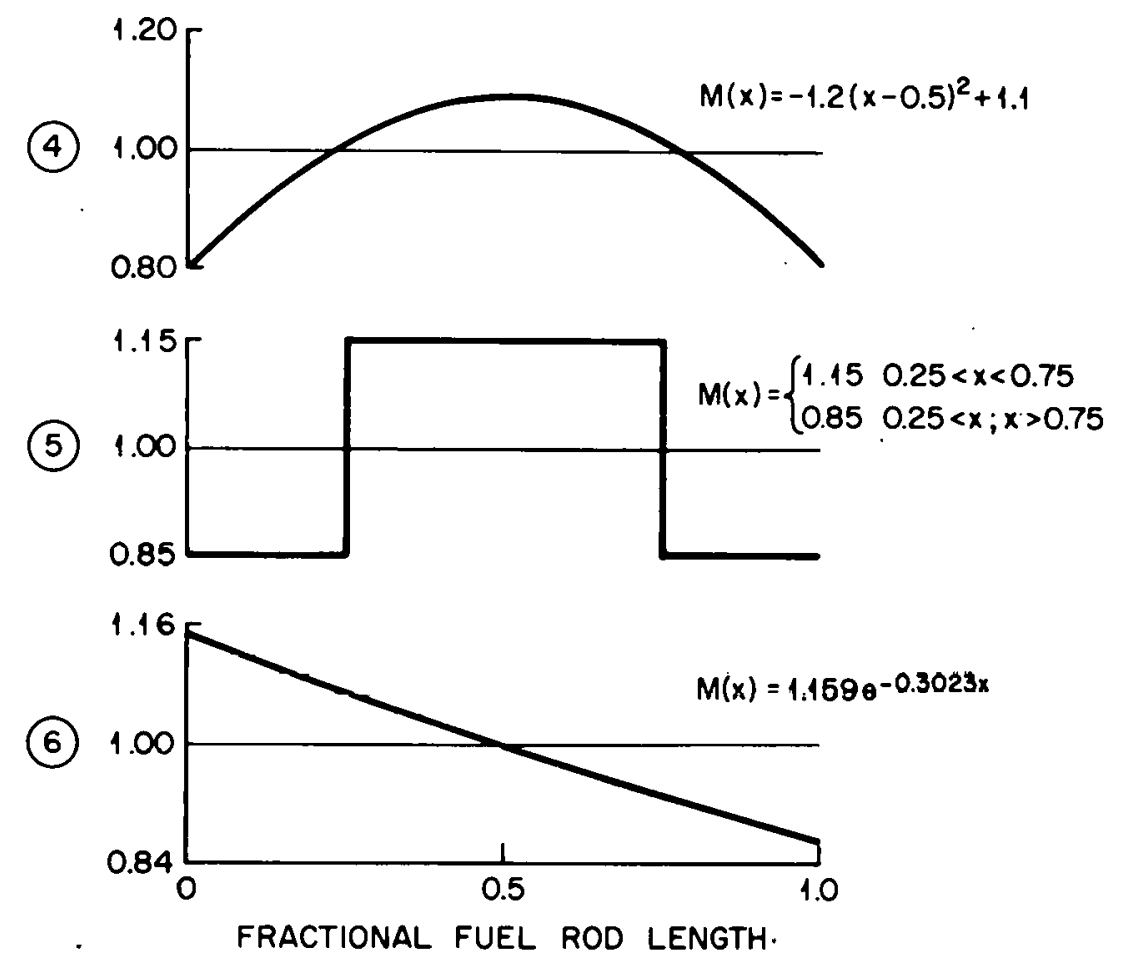

Fig. 3.6.(cont.) Hypothetical fissile mass distributions used to study the effects of axial fuel heterogeneities.

calibration rods to several worst-case estimates of production foul-ups. Note that each of the mass distribution functions has been normalized to a unit mass in each rod. Each mass distribution was multiplied by the flux function and the detector function. The product was integrated over the length of the fuel rod to get six values proportional to the device response for those distributions. The results (see Table 3.4) show that large variations in mass concentrations $( \pm 15 \%)$ have only a small effect ( $\sim 0.4 \%$ ) on assay accuracy. Cases 4 and 5 have the largest effect on accuracy, but the probability of ever encountering these distribution types is very small.

Table 3.4. Effect of variations in axial fissile concentration nn assay response

\begin{tabular}{ll}
\hline \multicolumn{1}{c}{ Uranium distribution } & $\int \phi(X) \epsilon(X) M(X) d x$ \\
\hline$M(x)=1.00$ & 1.0000 \\
$M(x)=1.15-0.3 x$ & 1.0000 \\
$M(x)=1.15, x<0.5$ & 1.0000 \\
$M(x)=-1.2(x-0.5)^{2}+1.1$ & 1.0029 \\
$M(x)=1.15,0.7 .5<x<0.75$ & 1.0041 \\
$0.85,0.25<x ; x>0.75$ & 1.0002 \\
\hline
\end{tabular}


Radial effects. As in the case of axial fuel concentration differences between calibration standards and unknowns, radial differences also have a potential effect on assay accuracy. In general, variations in the irradiator flux, the detector efficiency, and the mass distributions are responsible for potential assay biases. However, in this case, the detector efficiency does not play a significant role. Since delayed neutrons are emitted from precursors with relatively high energy (200 to $600 \mathrm{keV}$ ), the neutrons can easily escape from a fuel sample whether they are born in the center or on the surface of the fuel. Thus, detector sensitivity is independent of radial position and is eliminated from this consideration.

The thermal-neutron radial flux profile in the vicinity of the sample chamber is the major contributor to radial assay biases. Here, neutron self-shielding effects cannot be ignored. The magnitude of these biases has been estimated through the use of a one-dimensional calculational model of the irradiator. The geometry of the model was based on infinite-height concentric cylinders. The center region was composed of nuclear fuel material having a diameter equal to that of a typical fuel sample $(\sim 1.27 \mathrm{~cm})$. This region was surrounded by multiple annular regions of polyethylene and water. A very thin annular region was used to simulate the rotating neutron source. It was located $3.5 \mathrm{~cm}$ from the central axis. A 123-energy group, transport theory calculation was used to determine the neutron flux. The XSDRNPM module of the $\mathrm{AMPX}^{2}$ computer code system performed the calculation. Neutron interaction cross sections were taken from the ENDF/B-IV data file.

Three fissile concentration gradients typical of calibration standards and worst-case production specimens were studied. On a unit-length basis, each fuel sample had the same total amount of fissile material. In the first case, the fissile material was given a uniform radial concentration. The second case corresponded to a $14 \%$ increase, linear with radius, in fissile concentration from the center to the surface of the fuel sample. The third case was the inverse of the second. It contained a $14 \%$ radial decrease in fissile concentration from center to edge. For each case, the total number of counts accumulated during a fixed measurement was calculated. It was found that a $0.36 \%$ lower assay response was associated with both gradients compared with the uniform case. Thus, radial assay biases are approximately equal to axial effects. Large fissile concentration differences between standards and unknowns generate small assay biases.

Azimuthal effects. The last whole-sample spatial effect on accuracy is due to fissile concentration variations in the azimuthal direction. Measurements were made on three specimens exhibiting extreme azimuthal heterogeneities. Figure 3.7 shows the location of fissile material in a cross-sectional view of the three specimens. Each specimen contained the same total mass of fissile material. However, the assay system response to the three specimens varied by $5 \%$, with specimen 1 giving the highest response and specimen 2 the lowest response. Specimen 3 gave a response $1.7 \%$ higher than specimen 2 . Fortunately, production variations in azimuthal fissile concentration are not expected to be nearly as severe as those illustrated in Fig. 3.7. Consequently, it is believed that these effects will not be greater than a few tenths of a percent.

3.2.2.2 Fissile particle characteristics. The response of the assay system can be biased by differences between the fissile particle characteristics of calibration standards and unknown samples. The prinary factors influencing the system response are the density and volume of individual fissile particle kernels. The impact of variations in each of these variables is described below.

Kernel density effects. An experiment was conducted to determine the effect of fuel particle kernel density on the assay device response. Calibrated fuel rod standards were fabricated with particles of high-density kernels $\left({ }^{235} \mathrm{U}\right.$ density, $\left.8.34 \mathrm{~g} / \mathrm{cm}^{3}\right)$. The standard rods covered a range of fissile contents up to

$0.5 \mathrm{~g}{ }^{235} \mathrm{U}$. These rods were measured and compared with measurements made on rods composed of low-density kernel particles. $\left({ }^{235} \mathrm{U}\right.$ density, $\left.2.23 \mathrm{~g} / \mathrm{cm}^{3}\right)$. The resulting calibration curves are shown in Fig. 3.8. As expected, the assay device exhibits a lower response to the standards composed of high-dersily 
ORNL - OWG $78-14428$

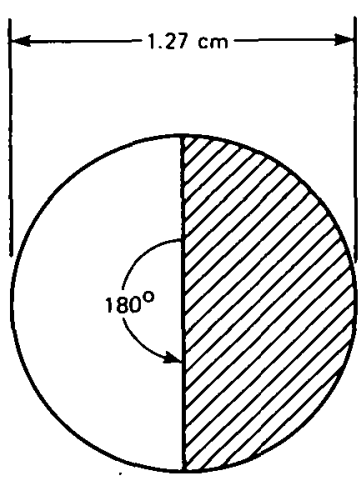

SPECIMEN 1

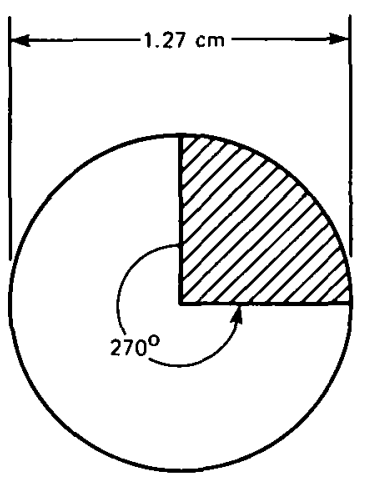

SPECIMEN 2

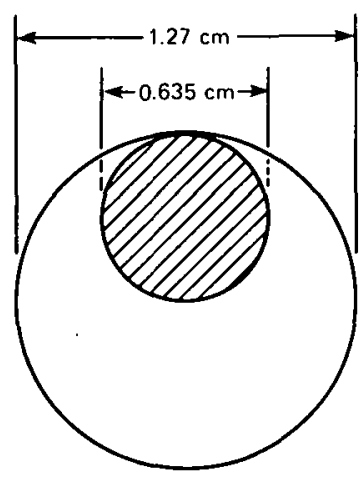

SPECIMEN 3

DIJ LOCATION OF FISSILE MATERIaL

Fig. 3.7. Cross-sectional views of specimens used to investigate the effects of azimuthal heterogeneities on fissile assay accuracy.

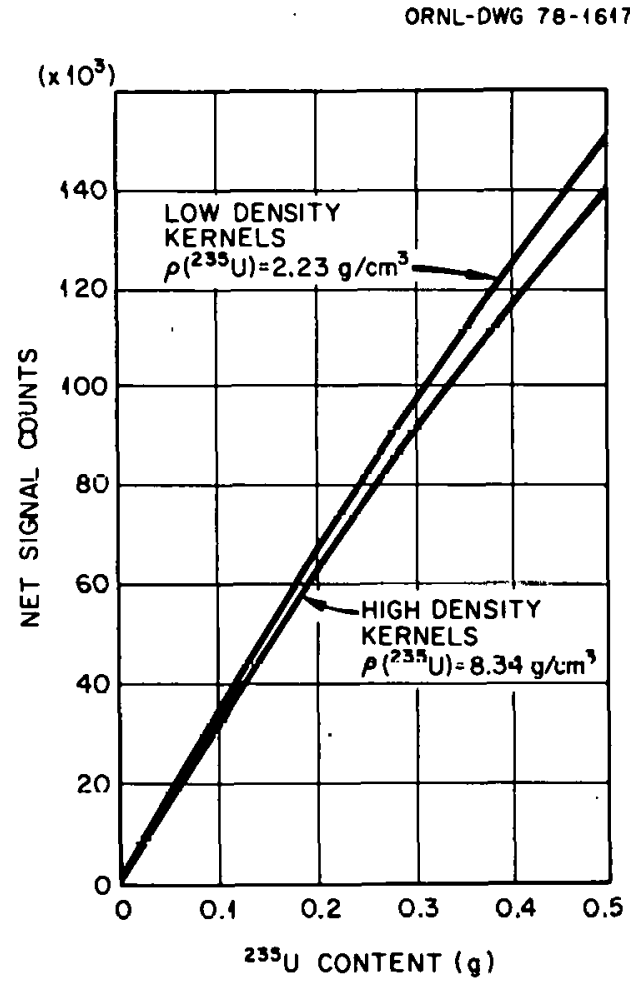

Fig. 3.8. Calibration curves for fuel rods composed of high- and low-density fuel kernels.

kernels in comparison with standards of the same uranium content in low-density kernels. This is due to the higher neutron self-shielding property of the high-density kernels. Specifically, the high-density kernels gave a response 5 to $8 \%$ lower than did the low-density kernels over a range of uranium loadings from 0.1 to 0.5 g. This leads to the conclusion that different calibration curves are required for widely different fuel kernel densities. For production, in which variations of the ${ }^{235} \mathrm{U}$ density in the kernels are not expected to exceed $5 \%$, biases in assay results will be less than $0.1 \%$. 
Kernel volume effects. Another experiment was conducted to investigate the effects of fuel kernel size on assay response. Fissile kernels of two different size ranges were fabricated. The first group had a mean kernel diameter of $375 \mu \mathrm{m}$, with minimum diameters of $370 \mu \mathrm{m}$ and maximum diameters of $380 \mu \mathrm{m}$. The second group had a mean diameter of $440 \mu \mathrm{m}$, with minimum kernel diameters of $430 \mu \mathrm{m}$ and maximum diameters of $450 \mu \mathrm{m}$. The density of each kernel batch was held constant at $1.63 \mathrm{~g} / \mathrm{cm}^{3}{ }^{235} \mathrm{U}$. Each group of kernels was processed separately through a coating operation and a fabrication process into fuel rods. Again, a range of rod fissile contents up to $0.5 \mathrm{~g}{ }^{235} \mathrm{U}$ was examined. Measurement of the rods revealed that net counts per gram of fissile material were approximately $1 \%$ lower for fuel rods composed of the larger particles. Thus a $17 \%$ change in average fissile kernel diameter causes a $1 \%$ effect on assay accuracy if calibration curves remain unchanged. Production variations in mean kernel diameters are again expected to be small, and assay biases are not expected to exceed $0.1 \%$.

3.2.2.3 Background activity. To minimize the potential biasing effects of changes in detector background count rates, measurements must be corrected for counts attributable to sources other than delayed neutrons. Fortunately, background counts for this device are small compared with delayed-neutron counts from samples in the 0.1- to $0.5 \mathrm{~g}$ fissile content range. Nevertheless, the corrections must be made.

The background activity originates from two neutron sources. The first of these is the fuel sample itself. Neutrons are released from unirradiated samples due to naturally occurring $(\alpha, n)$ reactions in the fuel matrix; This source is only observed in ${ }^{233} \mathrm{U}$ samples, which unavoidably include the highly alpha-active ${ }^{232} \mathrm{U}$ decay chain. The level of this background component is directly proportional to the ${ }^{232} \mathrm{U}$ content of the sample, and it is also dependent on the age of the material, since the activity of the ${ }^{232} \mathrm{U}$ decay chain increases with time. Peak activity of the chain is approached in an exponential fashion and is reached after ten years of undisturbed decay of an initially pure ${ }^{232} \mathrm{U}$ sample. Measurements have been made of the $(\alpha, n)$ background count rates in samples of uncarbonized fuel kernels. These indicate a 1-count/sec background from $0.5 \mathrm{~g}{ }^{233} \mathrm{U}$ having $\sim 7 \mathrm{ppm}{ }^{232} \mathrm{U}$ that is two years old. Reactor-grade ${ }^{233} \mathrm{U}$ may contain $\sim 1000 \mathrm{ppm}$ ${ }^{232} \mathrm{U}$, with assays being made up to six months after removal of ${ }^{232} \mathrm{U}$ decay products. Here, $(\alpha, n)$ count rates may be as high as 70 counts/sec and constitute $5 \%$ of the total sample count. Using a 2-min measurement, count rates of this magnitude can be estimated to within $2 \%$ with $95 \%$ confidence. Thus, if not corrected for, changes in material age or differences in the ${ }^{232} \mathrm{U}$ content of calibration standards and unknowns could lead to an assay bias of a few percent. However, subtraction of this background from the gross count eliminates any possible bias. Perhaps $0.1 \%$ in precision uncertainty could be accounted for by this factor.

The second component of background activity results from minor detector sensitivity to the neutron source used in the system's irradiator and to other quantities of californium in use at TURF. As mentioned in Sec. 2.2.2, this activity leads to a detector count rate of $\sim 2$ counts $/ \mathrm{sec}$. Again, as in the case of the $(\alpha, n)$ background, correction for this leads to no assay bias. Assay precision is not significantly affected by this low background.

During operation, no distinction is made between the $(\alpha, n)$ background and the TURF environmental background. These are measured simultaneously by taking a total background count with the sample in the detector just prior to the first irradiation. In this way, only a single background correction is made to the measured gross count.

3.2.2.4 Source decay. The source used for neutron irradiation of fuel samples consists of $\sim 1 \mathrm{mg}{ }^{252} \mathrm{Cf}$. This isotope has a half-life of 2.64 years. Since system response is directly proportional to the neutron flux in the irradiator, which in turn is directly proportional to the neutron source strength, corrections must be made to measured net counts so that all measured counts will be on an equal flux basis. Failure to correct for source decay could lead to significant biases. If the correction is not made, ten days after the date of calibration a $0.7 \%$ bias will exist in all assays, and 100 days later a $7.5 \%$ bias will result. 
3.2.2.5 Sensitivity to fertile materials. Large quantities of fertile isotopes such as ${ }^{232} \mathrm{Th}$ and ${ }^{238} \mathrm{U}$ are often present in nuclear fuel materials. This is true in the case of HTGR fuel, where ${ }^{232} \mathrm{Th}$ is the primary fertile isotope. These isotopes are an important concern in the design of fissile assay systems because they will undergo fission if exposed to a high-energy neutron flux. In the case of the HTGR sample assay device, the sample irradiation flux is relatively well thermalized, but it also contains a fast component. Hence the device response will contain some small sensitivity to fertile materials, and assay results may be slightly biased due to variations in sample fertile content.

An experiment was conducted to determine the system's response to samples containing large amounts of fertile isotopes and no fissile material. These measurements could then be compared with identical measurements on samples containing both fissile and fertile material. The results of this study indicate that the ratio of the system's response to $1 \mathrm{~g}{ }^{232} \mathrm{Th}$ relative to that from $1 \mathrm{~g}{ }^{235} \mathrm{U}$ is $\sim 3.7 \times 10^{-4}$. On the basis of $1 \mathrm{~g}{ }^{233} \mathrm{U}$, the ratio is $\sim 1.0 \times 10^{-3}$. Since the highest expected ratio of fertile-to-fissile mass in HTGR fuel samples is 25 , system sensitivity to ${ }^{232} \mathrm{Th}$ will account for no more than $1.0 \%$ of the total response in ${ }^{235} \mathrm{U}$ samples and no more than $2.5 \%$ of the total response in ${ }^{233} \mathrm{U}$ samples.

System sensitivity to fertile isotopes can he adjuster fon in two possible waye. First, if the amount of ${ }^{232} \mathrm{Th}$ is known in both calibration standards and unknown samples to within a few percent, the fertile component of the system response can be subtracted out of the total signal in a fashion similar to background corrections. This procedure could result in assay biases of 0.1 to $0.2 \%$ in some cases. The second approach would require calibration standards to contain approximately the same amount of fertile material as in unknowns. In this case the response to ${ }^{232} \mathrm{Th}$ would be approximately equal in both calibrated standards and unknowns, and consequently very little bias would occur in assay results. While the second approach may be more accurate, it must also be pointed out that this procedure would require many more calibration standards than does the first method.

\subsection{Miscellaneous Investigations}

\subsubsection{System response to mixtures of ${ }^{233} \mathrm{U}$ and ${ }^{235} \mathrm{U}$}

As part of another investigation for detcrmining the individual masses of ${ }^{233} \mathrm{U}$ and ${ }^{235} \mathrm{U}$ in mixed systems, calibration data were collected on samples having a wide range of ${ }^{233} \mathrm{U}$ and ${ }^{235} \mathrm{U}$ contents. It was found that in dual fissile samples, the device response could be closely approximated (i.e., $\pm 1 \%$ ) by the function below:

$$
C^{\prime}=\left(\frac{A_{1} X^{23}}{X^{23}+R X^{25}}+\frac{A_{2} X^{25}}{X^{23}+R X^{25}}\right)\left[1-e^{-B\left(X^{23}+R X^{25}\right)}\right]
$$

where

$C$ is the number of counts accumulated by the detector,

$A_{1}, A_{2}, B$, and $R$ are constants,

$X^{23}$ and $X^{25}$ are the fissile masses of ${ }^{233}$. $U$ and ${ }^{235} U$ respectively.

Constants were found for the above function such that measurements of 11 samples having total fissile contents from 0.3 to $0.5 \mathrm{~g}$ and having ${ }^{233} \mathrm{U}$ fractions of $100,75,50,25$, and $0 \%$ agreed with the corrclation to within $\pm 1 \%$. 


\subsubsection{Detector response to neutron energy}

The MORSE computer code was used to calculate the relative efficiency of the detector assembly with respect to the energy of neutrons uniformly emitted throughout the volume of a typical fuel sample. Calculations were done at seven different neutron energies ranging from 0.025 to $4 \mathrm{MeV}$. The results of this study are plotted in Fig. 3.9. The purpose of this work was to determine neutron detection efficiencies for different groups of delayed neutrons. These were then used in calculations to determine optimum assay operating procedures as reported in Sect. 3.2.1. The energies of delayed-neutron groups produced in ${ }^{235} \mathrm{U}$ fission range from 250 to $560 \mathrm{keV}$ and result in a detection efficiency for the high-energy group that is $13 \%$ lower than for the low-energy group.

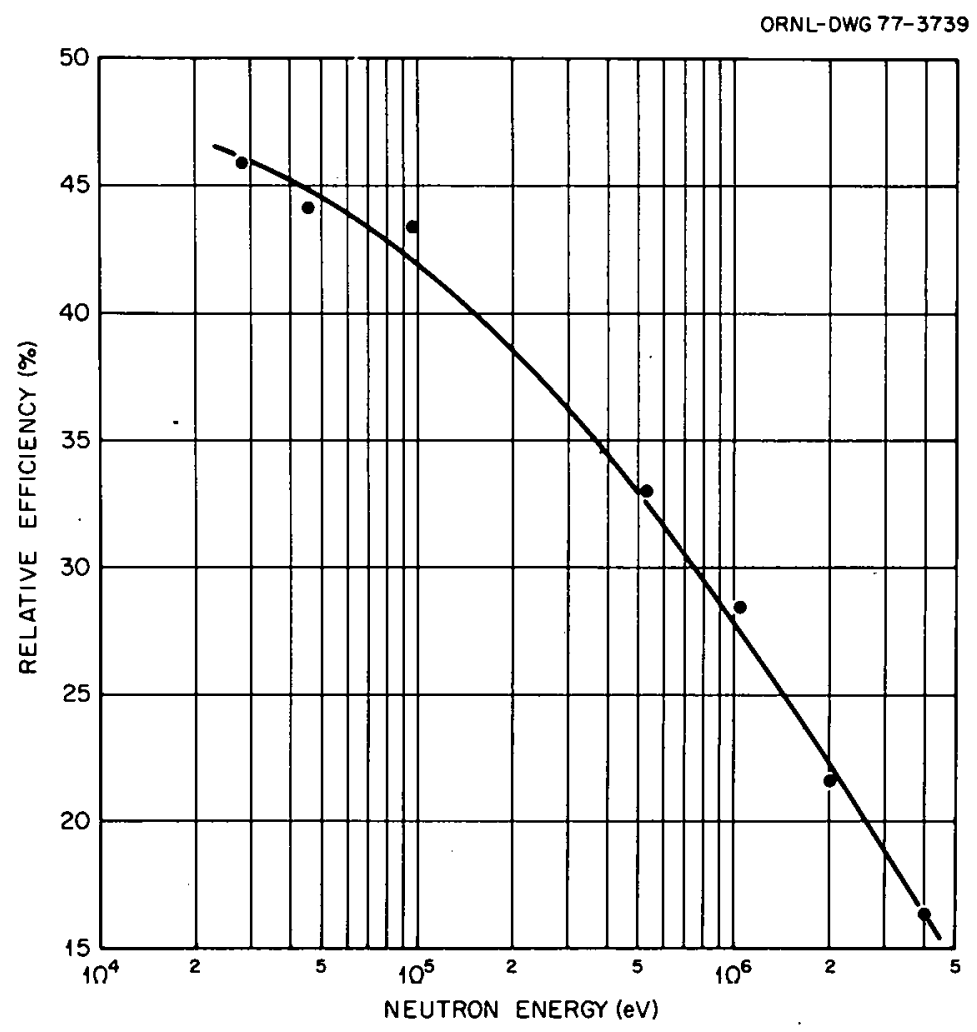

Fig. 3.9. Relative detector efficiency vs energy of neutrons emitted by sample.

\section{CONCLUSIONS AND RECOMMENDATIONS}

A nondestructive fissile assay system has been designed, constructed, and tested as part of the HTGR Fuel Recycle Development Program. The purpose of this device has been to demonstrate a technology that allows rapid ( $\sim 10 \mathrm{~min} /$ assay) nondestructive measurement of the fissile content of HTGR fuel samples. Although the system was designed for operation with HTGR fuel samples, it would be well suited for measurements on small samples of most any nuclear fuel that is not highly gamma-active (e.g., spent fuel). The device is intended to serve as a quality-control instrument in a sample inspection station and also as one component of an integrated nuclear safeguards system for an entire fuel recycle facility. Overall; the assay system is considered to be of engineering scale; however, two main components (i.e., neutron irradiator and delayed-neutron detector) are very nearly prototypic in design. 
Tests of the device focused primarily on evaluations of the system's precision and accuracy in measurements on fuel samples containing ${ }^{233} \mathrm{U}$ and ${ }^{235} \mathrm{U}$. In performing the many measurements required to evaluate precision and accuracy, it was found that the system exhibits highly-reliable operation. Results of evaluative testing indicate that the device is easily capable of producing the required precision of $\pm 0.3 \%$ when using 10-min measurements. Careful control of calibration procedures must be maintained to eliminate possible biases in assay results. It is believed that biases of less than $0.2 \%$ can be achieved with a well-calibrated assay device operating in a well-controlled fuel production environment.

Recommendations for upgrading the device to a prototypic scale are as follows:

1. Replace the existing pneumatic transfer components with new equipment meeting the proposed design requirements ${ }^{7}$ for fuel sample transfer in the HTGR Fuel Recycle Facility.

2. Automate the data analysis task to have a computer generate immediate assay results at the end of an irradiation and count series.

3. Install an automatic sample loading mechanism that would allow an operator to prepare 20 samples for assay and then return several hours later to examine the results.

\section{ACKNOWLEDGMENTS}

The authors thank the numerous members of the ORNL staff who assisted in the design and construction of the assay device. Notable among these are the following persons: S. P. Baker procured the PLC, supervised construction of the control panel, and provided helpful information on the use of the PLC. M. M. Chiles aided in the design of the detector system and supervised the construction of the detector. S. K. Fraley performed the MORSE computer code calculations in support of the detector design. J. E. Rushton provided many useful ideas pertaining to the overall design of the assay device.

In addition, many thanks go to the individuals who helped with the preparation of this report. E. J. Allen and G. L. Ragan provided excellent technical reviews. H. R. Livesey and M. A. Patrizio prepared the illustrations, and editing and composition were provided by Adroit, Inc.

\section{REFERENCES}

1. J. D. Jenkins, S. R. McNeany, and J. E. Rushton, Conceptual Design of the Special Nuclear Material Nondestructive Assay and Accountability System for the HTGR Fuel Refabrication Pilot Plant, ORNL/TM-4917 (July 1975).

2. N. M. Greene et al., AMPX: A Modular Code System for Generating Coupled Multigroup NeutronGamma Libraries from ENDF/B, ORNL/TM-3706 (March 1972).

3. Neutron Activation Analysis of Natural Uranium by Counting Delayed Neutrons from ${ }^{235} U ;$ Preliminary Considerations, unpublished report by LASL personnel; obtained from J. F. Emery, Analytical Chemistry Division, ORINL.

4. E. A. Straker, W. H. Scott, Jr., and N. R. Byrn, MORSE General Purpose Monte Carlo Multi-Group Neutron and Gamma-Ray Transport Code with Combinatorial Geometry, RSIC Computer Code Collection Report CCC-127D, Oak Ridge National Laboratory, 1972.

5. C. K. Bayne and S. R. McNeany, Statistical Precision of Delayed Neutron Nondestructive Assay Techniques ORNL/TM-6569 (in publication).

6. 5TI Programmer Operator's Manual, Texas Instruments Industrial Controls Publication 654 (1974).

7. J. E. Mack and R. R. Suchomel, Development of Systems for Sampling and Sample 'Iransfer of ${ }^{233}$ U Recycle Fucl (in preparation). 


\section{APPENDIX A}

\section{MODIFICATIONS MADE TO PNEUMATIC TRANSFER SYSTEM}

The following changes were made to the pneumatic transfer system as supplied by the vendor.

1. The loader-receiver was replaced by an ORNL-designed load-unload station.

2. A foam-rubber cushion ( $0.7 \mathrm{~cm}$ thick) was installed at the detector end to cushion the fall of the rabbit.

3. A copper tee was added near the irradiator to create a dead-air space in the irradiator end.

4. The exhaust port of solenoid $\mathrm{D}$ was plugged.

5. Solenoid $F$ was added with a globe valve on its exhaust to adjust the orifice.

6. Photoelectric sensors were added to detect the passage of rabbits and signal propulsion valves to close. 


\section{THIS PAGE \\ WAS INTENTIONALLY \\ LEFT BLANK}




\section{APPENDIX B}

\section{PROGRAMMABLE LOGIC CONTROLLER PROGRAM}

The PLC program used to operate the assay device is represented in ladder diagram form in Fig. B.1. Each program step is represented by a rung in the ladder, bracketed by the two sides of the $120 . \mathrm{V}$ ac power line. The elements that are controlled (outputs) are located on the right-hand side of the rungs (in circles). The output state is determined by the state of the elements on the left-hand side, which are combinations of timers, counters, and input switches. Table B.1 lists the components to which each input and output module is connected. As an example, in step $\mathrm{F}$ of the program, output $\mathrm{Y} 2$ is energized if contact $\mathrm{X} 8$ is closed and $\mathrm{Y} 3$ is open (so $\overline{\mathrm{Y}} 3$ is closed). In other words, if photoelectric sensor 1 (input module 8 ) is triggered by the rabbit as it travels toward the irradiator (in which case solenoid" valve $D$, wired to $Y 3$, is off), then the panel display light wired to output module Y2 will light up.

A complete listing of the assay program is supplied in Table B.2. For a detailed discussion of PLC programming and use of the various elements such as timers, counters, and control relays, the reader is referred to the 5TI 2000 Operator's Manual. ${ }^{6}$

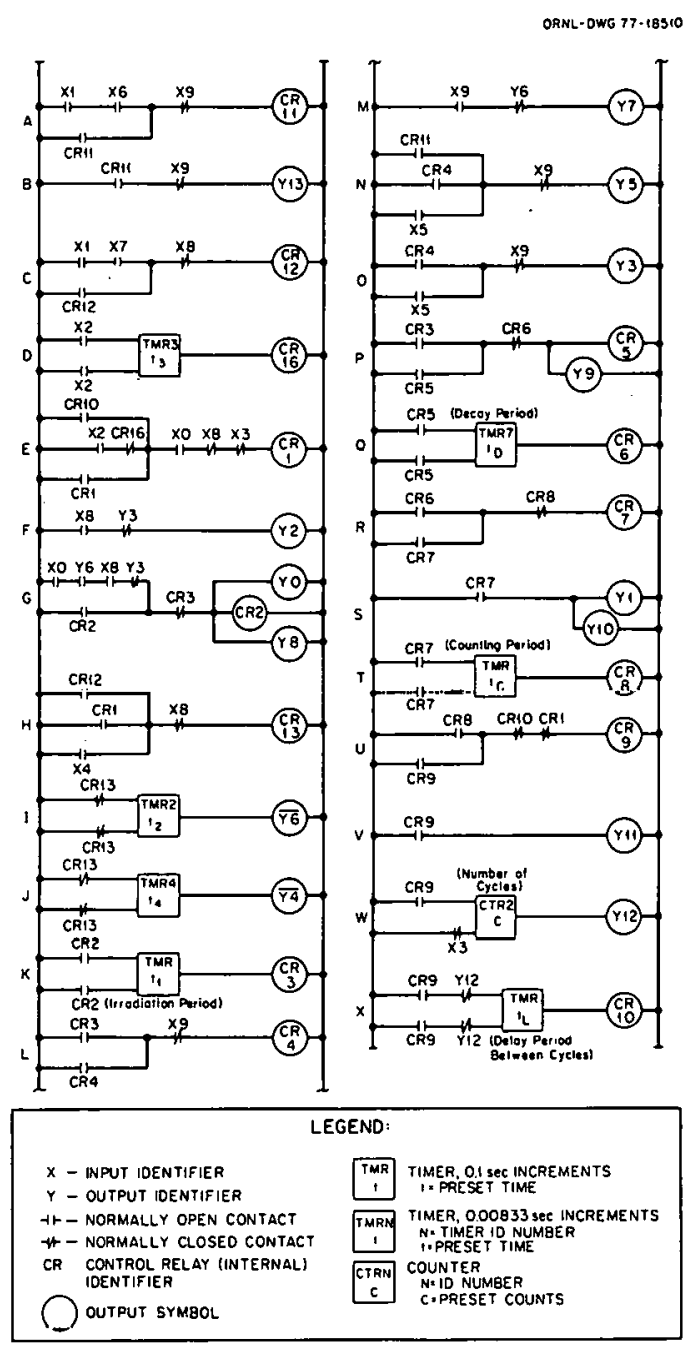

Fig. B.1. Ladder diagram representation of PLC program for control of the delayed-neutron-type assay device. 
Table B.1. Programmable logic controller input-output designations

\begin{tabular}{|c|c|c|}
\hline \multicolumn{2}{|c|}{ PLC. I/O number } & liunction ${ }^{a}$ \\
\hline \multirow[t]{10}{*}{ Input } & 0 & ENABLE: \\
\hline & 1 & DISABLE \\
\hline & 2 & SERIES-START \\
\hline & 3 & SERIES-RESET \\
\hline & 4 & MANUAL OVERIDE $b$ (TRANSIEER RABBIT TOWARD IRRADIATOR) \\
\hline & 5 & MANUAL OVERIDE ${ }^{b}$ (TRA NSFER RABBIT TOWARD DETECTOR) \\
\hline & 6 & $\mathrm{LOAD}^{b}$ \\
\hline & 7 & $\mathrm{UNLOAD}^{b}$ \\
\hline & 8 & PHOTOE LECTRIC CONTROL SIGNAL I (IRRADIATOR END) \\
\hline & 9 & PHOTOE LECTRIC CONTROL SIGNAL 2.(DETECTOR END) \\
\hline \multirow[t]{14}{*}{ Output } & 0 & LIGHT, $c$ IRRADIATOR \\
\hline & 1 & LIGHT, DELAYED NEUTRON DETECTOR \\
\hline & 2 & LIGHT, PHOTOELECTRIC SENSOR NUMBER 1 \\
\hline & 3 & LIGHT, IR.R.ADIATOR, END AIR INPUT VALVE: SOLENOID D \\
\hline & 4 & LIGH'I, IRLADIATOR END AIR EXIIAUST VALVE: SOLENOIDF \\
\hline & 5 & LIGHT, DETECTOR END EXHAUST VALVE: SOLENOID B \\
\hline & 6 & LIGHT, DETECTOR END AIR INPUT VALVE: SOLENOID A \\
\hline & 7 & LIGHT, BLEED-AIR SUPPLY: SOLENOIDS B \& C \\
\hline & 8 & LIGHT, IRRADIATION IN PROGRESS \\
\hline & 9 & LIGHT, DECAY PERIOD \\
\hline & 10 & LIGHT, COUNTING PERIOD: EXTERNAL GATE ON SCALER \\
\hline & 11 & LIGHT, END OF CYCLE \\
\hline & 12 & LIGHT, END OF SERIES \\
\hline & 13 & LOAD/UNLOAD STATION AIR INPUT VALVE: SOLENOID E \\
\hline
\end{tabular}

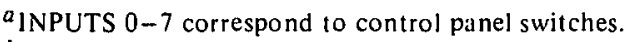

${ }^{b}$ Execute button must be pressed to accomplish this function.

${ }^{c}$ LIGHTS indicated in this column are control panel display lights.

Table B.2. PLC program steps for delayed-neutron assay device operation

\begin{tabular}{|c|c|c|c|c|}
\hline $\begin{array}{l}\text { Laddcr } \\
\text { component }\end{array}$ & & $\begin{array}{l}\text { Storage } \\
\text { location }\end{array}$ & & $\begin{array}{c}\text { Element } \\
\text { description }\end{array}$ \\
\hline A & & $\begin{array}{l}0 \\
1 \\
2 \\
3 \\
4\end{array}$ & . & $\begin{array}{l}\text { STR } \times 1 \\
\text { AND X6 } \\
\text { OR CR } 11 \\
\text { AND NOT X9 } \\
\text { OUT CR } 11\end{array}$ \\
\hline B & & $\begin{array}{l}5 \\
6 \\
7\end{array}$ & & $\begin{array}{l}\text { STR CR C I } \\
\text { AND NOT X9 } \\
\text { UU'I YI3 }\end{array}$ \\
\hline C & & $\begin{array}{r}8 \\
9 \\
10 \\
1 \text { i } \\
12\end{array}$ & & $\begin{array}{l}\text { STR X1 } \\
\text { AND X7 } \\
\text { OR CR } 12 \\
\text { AND NUI X8 } \\
\text { OUT CR12 }\end{array}$ \\
\hline D & $\cdot$ & $\begin{array}{l}13 \\
14 \\
15 \\
16 \\
17 \\
18\end{array}$ & . & $\begin{array}{l}\text { STR X2 } \\
\text { STR X2 } \\
\text { TMR3 } \\
t_{3} \\
\text { OUT CR } 16\end{array}$ \\
\hline$E$ & & $\begin{array}{l}19 \\
20 \\
21\end{array}$ & & $\begin{array}{l}\text { STR X2 } \\
\text { AND NOT CR } 16 \\
\text { OR CR } 10\end{array}$ \\
\hline
\end{tabular}


Table B.2 (continued)

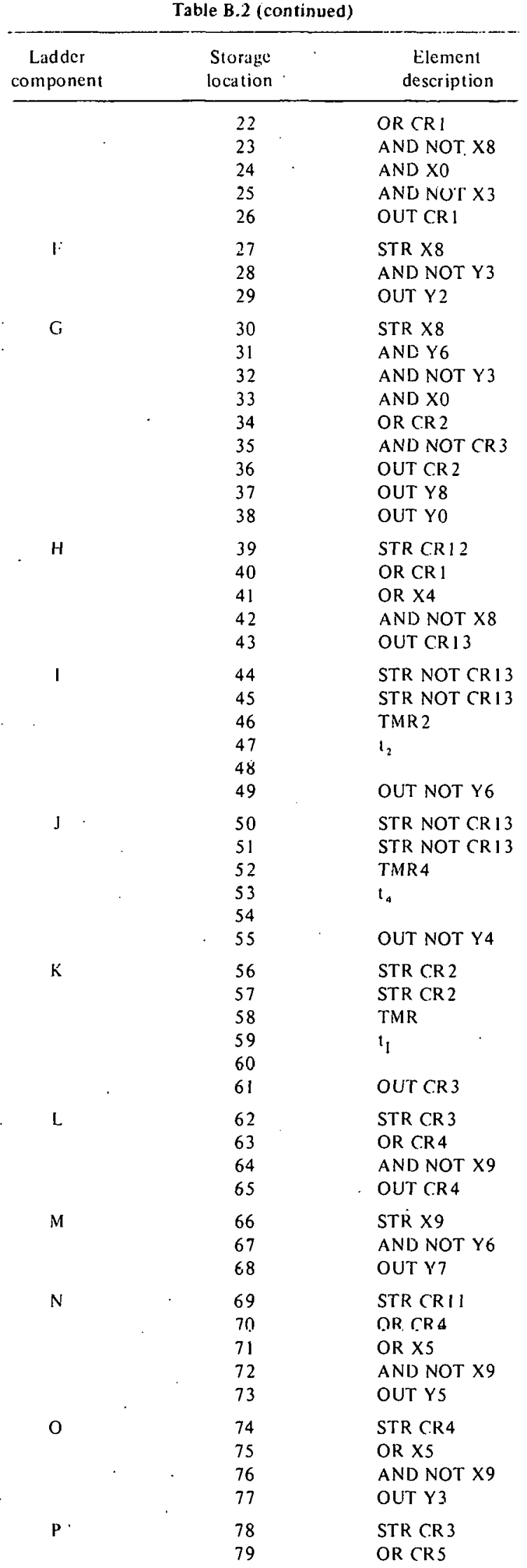


Table B.2 (continued)

\begin{tabular}{|c|c|c|}
\hline $\begin{array}{l}\text { Ladder } \\
\text { component }\end{array}$ & $\begin{array}{l}\text { Storage } \\
\text { location }\end{array}$ & $\begin{array}{c}\text { Element } \\
\text { description }\end{array}$ \\
\hline & $\begin{array}{l}80 \\
81 \\
82\end{array}$ & $\begin{array}{l}\text { AND NOT CR6 } \\
\text { OUT CR5 } \\
\text { OUT Y9 }\end{array}$ \\
\hline$Q$ & $\begin{array}{l}83 \\
84 \\
85 \\
86 \\
87 \\
88\end{array}$ & $\begin{array}{l}\text { STR CR5 } \\
\text { STR CR5 } \\
\text { TMR7 } \\
t_{1} \\
\text { OUT CR6 }\end{array}$ \\
\hline $\mathbf{R}$ & $\begin{array}{l}89 \\
90 \\
91 \\
92\end{array}$ & $\begin{array}{l}\text { STR CR6 } \\
\text { OR CR7 } \\
\text { AND NOT CR } 8 \\
\text { OUT CR7 }\end{array}$ \\
\hline$S$ & $\begin{array}{l}93 \\
94 \\
95\end{array}$ & $\begin{array}{l}\text { STR CR7 } \\
\text { OUT Y10 } \\
\text { OUT Yl }\end{array}$ \\
\hline 'I' & $\begin{array}{r}96 \\
97 \\
98 \\
99 \\
100 \\
101\end{array}$ & $\begin{array}{l}\text { STR CR 7 } \\
\text { STR CR7 } \\
\text { TMR } \\
\text { t. } \\
\text { OUT CR8 }\end{array}$ \\
\hline $\mathrm{U}$ & $\begin{array}{l}102 \\
103 \\
104 \\
105 \\
106\end{array}$ & $\begin{array}{l}\text { STR CR } 8 \\
\text { OR CR } 9 \\
\text { AND NOT CR } 10 \\
\text { AND NOT CR I } \\
\text { OUT CR9 }\end{array}$ \\
\hline$v$ & $\begin{array}{l}107 \\
108\end{array}$ & $\begin{array}{l}\text { STR CR9 } \\
\text { OUT 'Ill }\end{array}$ \\
\hline$w$ & $\begin{array}{l}109 \\
110 \\
111 \\
112 \\
113 \\
114\end{array}$ & $\begin{array}{l}\text { STR CR } 9 \\
\text { STR NOT X3 } \\
\text { CTR? } \\
\sigma_{2} \\
\text { OUT Y12 }\end{array}$ \\
\hline$x$ & $\begin{array}{l}115 \\
116 \\
117 \\
118 \\
119 \\
120 \\
121 \\
122\end{array}$ & $\begin{array}{l}\text { STR CR9 } \\
\text { AND NOT Y } 12 \\
\text { STR RR.9 } \\
\text { AND NOT Y } 12 \\
\text { TMR } 8 \\
\mathrm{t}_{\mathrm{L}} \\
\text { OUT CR } 10\end{array}$ \\
\hline
\end{tabular}

NOTL: Operator-set parameters

\begin{tabular}{|c|c|}
\hline $\begin{array}{l}\text { Storage } \\
\text { Location }\end{array}$ & Definition \\
\hline 59 & Irradiation time \\
\hline 86 & $\begin{array}{l}\text { Time between end of } \\
\text { irrudiution and sturt } \\
\text { of counting }\end{array}$ \\
\hline 99 & Counting time \\
\hline 112 & Total number of cycles \\
\hline 120 & $\begin{array}{l}\text { Time between end of } \\
\text { count ing and start of } \\
\text { next cycle }\end{array}$ \\
\hline
\end{tabular}




\section{APPENDIX C \\ OPERATING PROCEDURE}

\section{C.1 Preliminary Preparation of Assay Device}

Pneumatic system. Usually the pneumatic transfer system does not need adjustment. However, if the current rabbit design is changed or if sample weights change significantly, changes in system pressure may be required to push the rabbit over the hills in the transfer lube. Changes in system pressure are made by adjusting the pressure regulators located on the air input lines to the detector, the irradiator, and the sample loader-unloader.

Detector system. The electronic components should be set as follows:

$\begin{array}{ll}\text { TC940 H.V. supply } & 1000 \mathrm{~V} \mathrm{dc} \\ \text { TC203BLR linear amp } & \text { Coarse gain }=200 \\ & \text { Fine gain }=0.8 \\ & \text { Time constant }=2 \mu \mathrm{sec} \\ & \text { Output: direct } \\ & \text { Rate: high } \\ \text { TC441 single-channel } & \text { Mode: } \mathrm{E} \\ \text { analyzer } & \mathrm{E}=1.0 \mathrm{~V} \\ \text { TC546P scaler } & \text { Reset counts to zero }\end{array}$

Control panel - PLC system. If changes are to be made to the assay system's operating parameters (i.e., irradiation time, counting time, or number of irradiation and count cycles), these can be easily and quickly made through the timer-counter access module. This unit is mounted in the control rack next to the PLC sequencer. The push-button controls on the front of the access module allow the operator to set any times or number of counts into the existing program. Detailed instructions on the use of this module are supplied in the unit's owner's manual.

After completing any changes in the operating parameters, the two switches that activate the photoelectric sensors must be turned on. Also, the master control relay at the top of the control rack must be in the "delayed-neutron assay" position.

Before proceeding with the insertion of the ${ }^{252} \mathrm{Cf}$ neutron source into the irradiator, the operator should test the operation by loading a dummy sample into the systern (see steps below) and performing a test run.

Irradiator. Remotely remove the ${ }^{252} \mathrm{Cf}$ source from its storage tank in cell $\mathrm{B}$. Unscrew the source tube handle and insert source tube into irradiator. Turn on the motor that rotates the source.

\section{C.2 Assay Procedure}

To perform an assay, the following steps must be followed:

1. Insert rabbit with encapsulated sample into sample loader.

2. Activate the controls of the loader to rotate the rabbit into alignment with the loading branch of the transfer tube.

3. Check the rabbit diverter valve to be sure that it connects the loading branch with the main transfer tube. Reposition it if necessary. 
4. Set the LOAD/UNLOAD switch to the LOAD position and press EXECUTE. This should transfer the rabbit into the detector. If it does not, check to see that the ENABLE/DISABLE switch is in the DISABLE position and the START/RESET switch is in the RESET position. Adjust accordingly and press EXECUTE again.

5. Measure the background count rate and record.

6. Position the rabbit diverter valve in the position to transfer the rabbit into the irradiator.

7. Switch to ENABLE. Switch to START. This should start the automatic sequence of irradiation and count cycles. At its completion, the light labeled END OF SERIES will be lit, and the unloading operation can begin.

8. Switch the rabbit diverter valve to direct the rabbit to the unload station.

9. Switch to DISABLE. Switch to RESET. Switch to UNI_OAD. Press EXECUTE. The rabbit should be transferred to the urluades.

10. Activate the controls of the unloader to rotate the sample to the dump position and around to the verticle load position in preparation to receive a new sample.

11. Record the number of counts accumulated on the scaler and the operating parameters used for the measurement.

12. Reset scaler.

NOTE: If it is necessary to prematurely terminate a cycle, push ABORT, flip to DISABLE and RESET, and cancel ABORT. Use manual override to return rabbit to detector end. 
ORNL/TM-6610

Distribution

Category UC-77

Internal Distribution

1-2. Central Research Library

3. Document Reference Section

4-6. Laboratory Records Department

7. Laboratory Records, ORNL RC

8. ORNL Patent Office

9-18. E. J. Allen

19. P. Angelini

20. W. J. Armento

21. S. M. Babcock

22. B. J. Bolfing

23. R. A. Bradley

24. A. J. Caputo

25. J. A. Carpenter, Jr.

26. D. A. Costanzo

27. F. J. Dyer

28. W. P. Eatherly

29. R. E. Helms

30. L. C. Hensley

31-33. M. R. Hill

34. F. J. Homan

35-39. J. D. Jenkins

40. D. R. Johnson
41. R. R. Judkins

42-52. P. R. Kasten

53-57. R. W. Knoll

58. W. J. Lackey

59. C. E. Lamb

60. R. J. Lauf

61. E. L. Long, Jr.

62. A. L. Lotts

63. J. E. Mack

64. R.W. McClung

65-69. S. R. McNeany

70. H. E. Reeser

71. J. E. Rushton

72. J. E. Selle

73. D. P. Stinton

74. S. M. Tiegs

75. R. W. Balluffi (Consultant)

76. P. M. Brister (Consultant)

77. W. R. Hibbard, Jr. (Consultant)

78. M. J. Mayfield (Consultant)

79. J. T. Stringer (Consultant)

\section{External Distribution}

80-81. DOE DIVISION OF NUCLEAR POWER DEVELOPMENT, Washington, DC 20545

Director

82. DOE IDAHO OPERATIONS OFFICE, P.O. Box 2108, Idaho Falls, ID 83401

Bariy Sritili

83. SAN-Development, San Diego Area Office, P.O. Box 81325, San Diego, CA 92138

Senior Program Coordinator

84. DOE SAN FRANCISCO OPERATIONS OFFICE, 1333 Broadway, Wells Fargo Building, Oakland, CA 94612

Manager

85. DOE OAK RIDGE OPERATIONS OFFICE, P.O. Box E, Oak Ridge, TN 37830 Assistant Manager, Energy Research and Development

86-262. DOE TECHNICAL INFORMATION CENTER, Office of Information Services, P.O. Box 62, Oak Ridge, TN 37830

For distribution as shown in TID4500 Distribution Category, UC-77 (Gas-Cooled Reactor Technology) 